University of Rhode Island

DigitalCommons@URI

Open Access Master's Theses

1972

\title{
Brain Sensitivity to Barbiturates and Brain Gamma-Aminobutyric Acid
}

Girish J. Patel

University of Rhode Island

Follow this and additional works at: https://digitalcommons.uri.edu/theses

\section{Recommended Citation}

Patel, Girish J., "Brain Sensitivity to Barbiturates and Brain Gamma-Aminobutyric Acid" (1972). Open Access Master's Theses. Paper 217.

https://digitalcommons.uri.edu/theses/217

This Thesis is brought to you for free and open access by DigitalCommons@URI. It has been accepted for inclusion in Open Access Master's Theses by an authorized administrator of DigitalCommons@URI. For more information, please contact digitalcommons-group@uri.edu. 
BRAIN SENSITIVITY TO BARBITURATES AND BRAIN GAMMA-AMINOBUTYRIC ACID

BY

GIRISH J. PATEL

A THESIS SUBMITTED IN PARTIAL, FULFILLMENT OF THE REQUIREMENTS FOR THE DEGREE OF MASTER OF SCIENCE IN PHARMACOLOGY AND TOXICOLOGY UNIVERSITY OF RHODE ISLAND 1972 


\title{
MASTER OF SCIENCE THESIS
}

OF

GIRISH J. PATEL

\section{Approved :}

Thesis Committee:
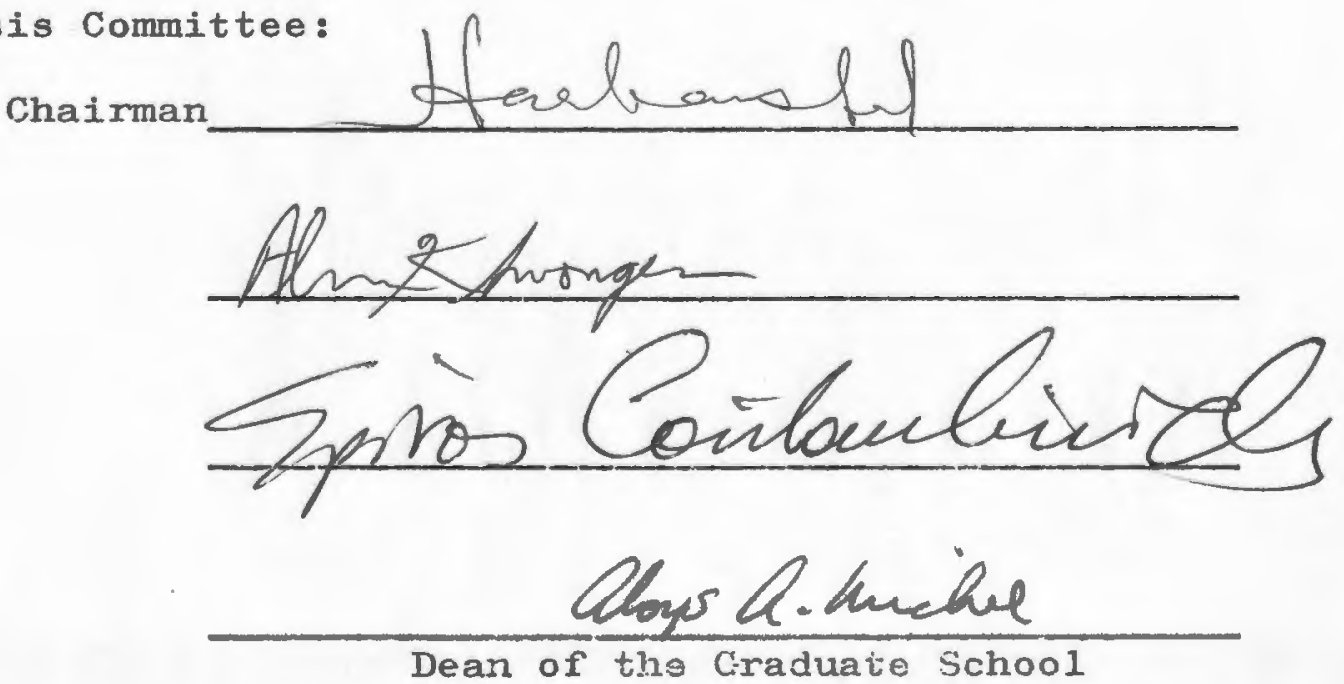

\author{
UNIVERSITY OF RHONE ISLAND \\ 1972
}




\begin{abstract}
The correlation between alteration in brain sensitivity to barbiturates and changes in brain gamma-aminobutyric acid levels was investigated. The following conditions were utilized to alter the brain sensitivity of mice or rats to barbiturates, 1) exposure to hypobaric hypoxia, 2) septal lesions, 3) treatment with desipramine, sodium nitrite or pargyline, 4) social deprivation, and 5) abrupt withdrawal following chronic barbiturate or ethanol administration. The first three of these conditions have been known to increase the brain sensitivity to barbiturates, while the last two conditions are known to decrease the sensitivity of brain neurons to barbiturates. The brain levels of gamma-aminobutyric acid were determined after the above treatments. Wherever necessary, the mechanism of alteration in gamma-aminobutyric acid was investigated by measuring activities of the enzymes, glutamic acid decarboxylase and gamma-aminobutyric acid transaminase.
\end{abstract}

Acute Hypoxia

Exposure of mice to hypobaric hypoxia (364 mm Hg, $\mathrm{pO}_{2}=76 \mathrm{~mm} \mathrm{Hg}$ ) for 30 or 60 minutes at 22 or $30^{\circ} \mathrm{C}$ ambient temperature, produced elevation in brain levels of gammaaminobutyric acid. Only hypoxia was found to affect brain 
gamma-aminobutyric acid. Ambient temperature or duration of hypoxia exposure did not affect or interact with the effect of hypoxia on brain gamma-aminobutyric acid. These data suggest that hypoxia induced-elevation in brain gammaaminobutyric acid may lower the threshold of brain neurons to drug induced depression.

\section{Septal Lesions}

Bilateral lesions of the septal area markedly potentiated narcosis due to barbital suggesting that alteration in neuronal excitability had taken place. There was no difference in the levels of brain gamma-aminobutyric acid between the septal rats and sham-operated or normal control rats. Therefore, the effect of septal lesions on the brain sensitivity does not appear to be related to alteration in brain gamma-aminobutyric acid.

\section{Drug Treatments}

Desipramine, ambient temperature and their interaction had a significant effect on brain gamma-aminobutyric acid. At $22^{\circ} \mathrm{C}$, desipramine produced hypothermia and elevated brain gamma-aminobutyric acid levels. At $30^{\circ} \mathrm{C}$ ambient temperature desipramine ceased to reduce body temperature and brain gamma-aminobutyric acid. In mice treated with desipramine at the lower ambient temperature, there was a dose-response relationship between the amount of drug administered and the elevation in brain gamma-amino- 
butyric acid. Hypothermia due to desipramine appears to be important in the elevation of brain gamma-aminobutyric acid. These findings suggest that reduced brain excitability due to high gamma-aminobutyric acid may alter the response of brain neurons to barbiturates.

At $22^{\circ} \mathrm{C}$, sodium nitrite produced hypothermia and raised brain levels of gamma-aminobutyric acid. At $30^{\circ} \mathrm{C}$ ambient temperature sodium nitrite ceased to affect body temperature and brain gamma-aminobutyric acid. Even though, hypothermia due to sodium nitrite seems to be important in elevation of gamma-aminobutyric acid, Elevation of gammaaminobutyric acid is the result of sodium nitrite's ability to produce hypoxia.

Pargyline induced potentiation of narcosis due to barbital was greater at $22^{\circ} \mathrm{C}$ than at $30^{\circ} \mathrm{C}$ ambient temperature. This suggested that pargyline alters the neuronal sensitivity to barbiturates at both the ambient temperatures. Pargyline also produced hypothermia and elevated brain gamma-aminobutyric acid at both the ambient temperatures. There was a greater degree of reduction in body temperature and elevation in brain gamma-aminobutyric acid when mice were treated with pargyline at $22^{\circ} \mathrm{C}$. In pargyline treated mice, at $22^{\circ} \mathrm{C}$, there was a dose-response relation ship between che amount of drug administiered and the degree of elevation in brain gamma-aminobutyric acid. These observations indicate that pargyline indused hypothermia causes elevation in brain ganma-aminobutyric acid. Further, 
the increased concentrations of brain gamma-aminobutyric acid may in turn lower the threshold of brain neurons to barbiturates.

\section{Social Deprivation}

Chronic deprivation of social stimuli lowered brain gamma-aminobutyric acid levels, decreased the activity of the gamma-aminobutyric acid synthesizing enzyme, glutamic acid decarboxylase and reduced total protein content in the brain. The activity of the gamma-aminobutyric acid degrading enzyme, gamma-aminobutyric acid transaminase, remained unaltered. These data suggest that reduced concentrations of gamma-aminobutyric acid might have raised arousal levels of the deprived mice such that their central nervous system susceptibility to drugs was altered. Further, reduced levels of gamma-aminobutyric acid were true reflections of glutamic acid decarboxylase.

\section{Drug Withdrawal}

The fluid intake of mice was restricted to increasingly concentrated solutions of phenobarbital for four weeks. Abrupt withdrawal resulted in convulsive activity in response to an auditory stimulation. There was no alteration in brain levels of gamma-aminobutyric acid in any of the groups tested. These data suggest that brain ganmaaminobutyric acid was not involved in the alteration of neuronal sensitivity following barbiturate withdrawal. 
Intoxicating blood levels of ethanol were maintained, by stabilizing blood ethanol-1evels with daily injections of pyrazole, for 96 hours in mice housed in an atmosphere of ethanol vapour. On removal from the ethanol, mice developed withdrawal signs. The signs were graded to indicate the time course and intensity of the withdrawal syndrome. Eight and twenty-four hours following ethanol withdrawal mice were tested with barbital. Both the groups showed marked reduction in narcosis due to barbital. These observations suggested that ethanol withdrawal heightened the threshold of brain neurons to drug induced depression. The brain levels of ganma-aminobutyric acid were found to be lowered following eight hours of ethanol withdrawal. This indicates that lower than normal brain gamma-aminobutyric acid may cause an increase in neuronal excitability, which is revealed upon administration of the barbiturate. 


\section{ACKNOWLEDGEMENTS}

I would like to express my sincere appreciation to Dr. Harbans Lal for his invaluable guidance throughout the duration of this study.

Also, I would like to acknowledge the other members of my committee, Drs. Spiros M. Constantinides and Alvin K. Swonger for their advice and assistance.

I am grateful to Messrs. Surendra K. Puri, Raja Gopala Reddy and Gerald Gianutsos and to the faculty in the Department of Pharmacology for their many helpfiul suggestions during these studies.

Also, I am deeply grateful to my parents, Mr. \& Mrs. Jagdishbhai D. Patel, without whom none of this would be possible.

The financial aid provided through a teaching assistantship by the Department of Pharmacology and a research grant from the Rhode Island Heart Association is gratefully acknowledged. 
TABLE OF CONTENTS

Page

ABSTRACT............................... i

ACKNOWLEDGENENTS. ........................ vi

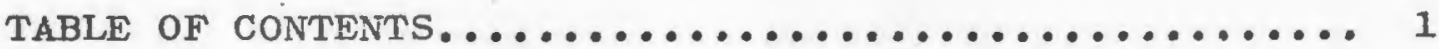

LIST OF TAELES........................... 3

LIST OF FIGURES.......................... 5

INTRODUCTION.............................. 6

LITERATURE SURVTY......................... 10

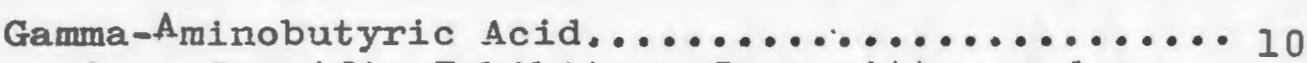
As a Specific Inhibitory Transmitter and a

Non-Specific Depressant Substance.......... 12 Gamma-Aminobutyric Acid and Convulsions...... 14

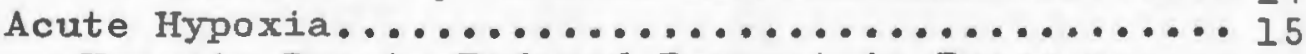

Hypoxia Due to Reduced Barometri.c Pressure.... I6

Hypoxia and Brain Sensitivity............. I6

Hypoxia and Gamma-Aminobutyric Acid......... 17

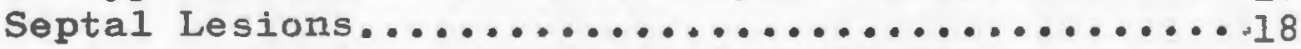

Septal Lesions and Brain Sensitivity........ I8

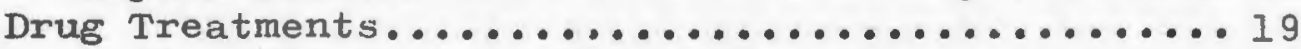

Sodium Nitrite and Brain Sensitivity........ I9

Desipramine and Brain Sensitivity.......... 20

Social Deprivation...................... 21

Social Deprivation and Brain Sensitivity..... 22

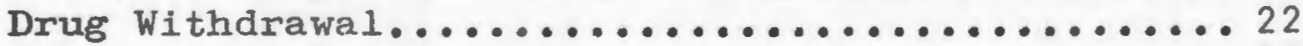

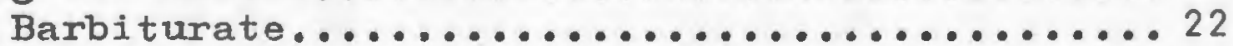

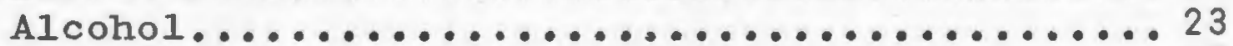

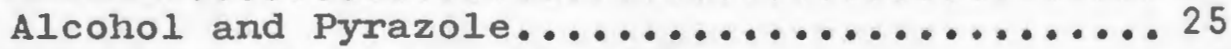

EXPERIMENTAL............................. 27

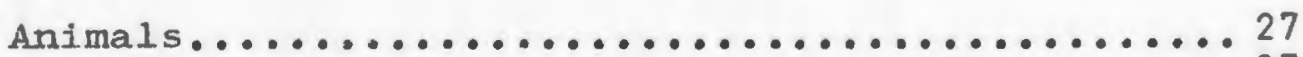

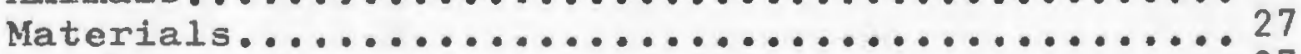

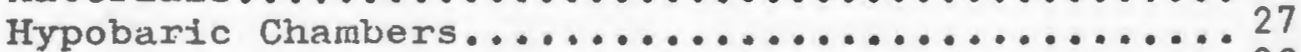

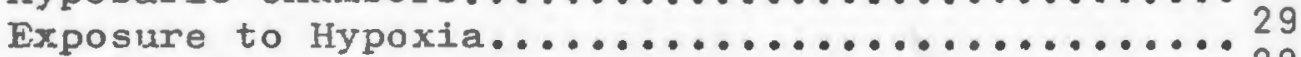

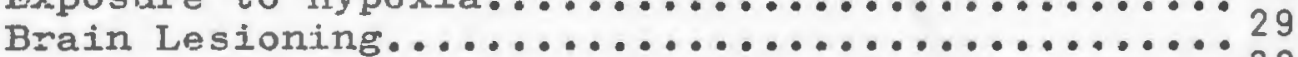

Measurement of Drug-Induced Narcosis........... 30

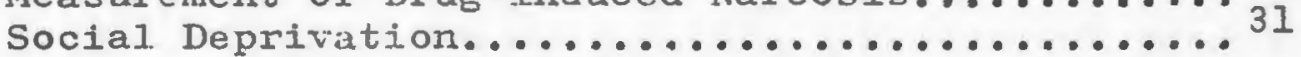

Chronic Plienobarbital Administration and

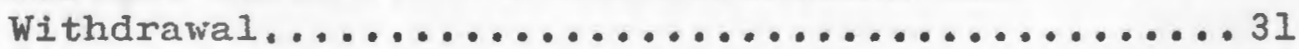

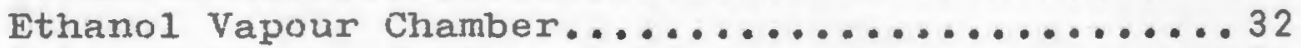

Deterinination of Ethanol Vapour-Concentration.... 34

Determination of Blood Ethanol-Levels..........34 
Page

Chronic Ethanol Intoxication and Withdrawa1.... 38

Measurement of Gamma-Aminobutaric Acjd........ 38

Measurement of Glutamic Acid Decarboxylase

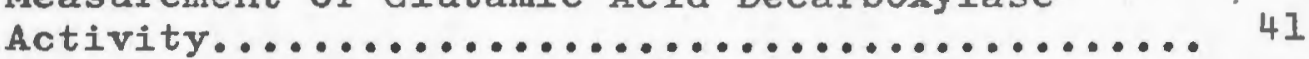

Measurement of Gamma-Aminobutyric Acid

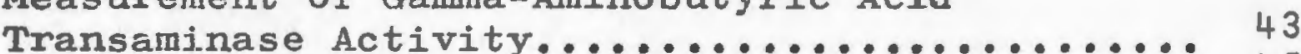

Determination of Brain Protein.............. 45

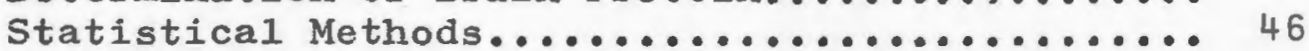

RESULTS.................................. 47

DISCUSSION.............................. 80

SUMMARY.................................. 91

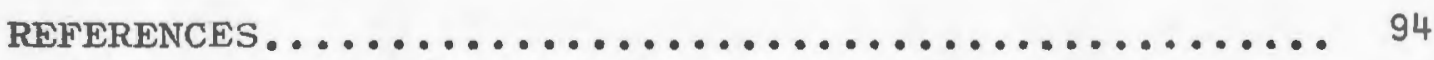

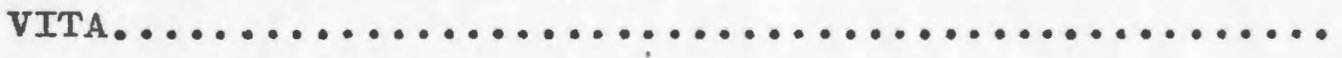




\section{LIST OF TABLES}

Table

Page

1 Effect of Hypobaric Hypoxia on Mouse Brain Levels of Gamma-Aminobutyric Acid at Two

Ambient Temperatures.......................

2 Effect of Septal Lesions on Barbital Narcosis and Brain Levels of Gamma-Aminobutyric Acid

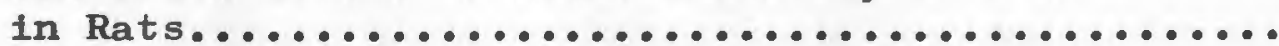

3 Effect of Dasipramine on Body Temperature and Brain Levels of Gamma-Aminobutyric Acid at Two Ambient Temperatures in Mice.................

4 Effect of Various Doses of Desipramine on Mouse Brain Levels of Gamma-Aminobutyric Acid at $22^{\circ} \mathrm{C}$ Ambient Temperature..................

5 Effect of Sodium Nitrite on Body Temperature and Brain Levels of Gamma-Aminobutyric Acid at Two Ambient Temperatures in Mice.............

6 Effect of Pargyline on Barbital Narcosis, Body Temperature and Brain Levels of GammaAminobutyric Acid at Two Ambient Temperatures In Mice.

7 Effect of Various Doses of Pargyline on Mouse Brain Levels of Gamma-Aminobutyric Acid at $22^{\circ} \mathrm{C}$ Ambient Temperature...............

8 Effect of Social Deprivation or Social Interaction on Mouse Brain Levels of GammaAminobutyric Acid.........................

9 Effect of Social Deprivation or Social Interaction on Mouse Brain Levels of GammaAminobutyric Acid, Glutamic Acid, Decarboxylase and Gamma-Aminobutyric Acid Transaminase and Protein.............................

10 Effect of Barbiturate Withdrawal on Mouse Brain Levels of Gamma-Aminobutyric Acid...........

11 Ethanol Withdrawal Syndrome.................

12 Duration of Barbital Narcosis in Mice Withdrawn from Ethanol....................... 
Table

Page

13 Effect of Ethanol Withdrawal on Mouse Brain

Levels of Gamma-Aminobutyric Acid.............. 78

14- Effect of Pyrazole on Barbital Narcosis and

Brain Levels of Gamma-Aminobutyric Acid in

Mice................................. 79 


\section{LIST OF FIGURES}

Figure

Page

1 Gamma-Aminobutyric Acid Shunt. . . ... . . 11

2 Hypobaric Chamber System . . . . . . . 28

3 Ethanol Vapour-Chamber System. . . . . . 33

4 Relationship Between Air-Flow and Chamber Air-Ethanol Concentration. . . . . . . . 35

5 Standard Curve for Quantitative Determination of Ethanol in Blood. . . . . . . . . . . 37

6 Blood Ethanol Concentrations During Exposure to Ethanol Vapours ... . . . . . . . 39

7 Effect of Various Doses of Desipramine on Mouse Brain Levels of Gamma-Aminobutyric Acid at $22^{\circ} \mathrm{C}$ Ambient Temperature . . . . . 55

8 Effect of Pargyline on Rectal Temperature of Mice at Two Ambient Temperatures... ... . 63

9 Effect of Various Doses of Pargyline on Mouse Brain Levels of Gamma-Aminobutyric Acid at $22^{\circ} \mathrm{C}$ Ambient Temperature... . . . 64 


\section{INTRODUCTION}

Various factors in the environment have been known to affect physiological processes within the organism resulting in altered pharmacological response. Factors such as ambient temperature (Chance, 1957), atmospheric pressure (Bernardini, 1969), population density (Chance and Mackintosh, 1962) and seasonal variations (Heller et al., 1957) may influence the onset, potency or duration of action of a drug thus altering the resultant pharmacodynamic activity. Treatments like hypoxia (Robinson et al., 1968), administration of sodium nitrite (Baumel et al., 1971) or desipramine (Shah and Lal, 1971), or prolonged social deprivation (Baumel et al., 1970a) have been reported to alter the CNS sensitivity to barbiturates. The other conditions which have been known to alter the neuronal sensitivity to barbiturates include, tolerance or physical dependence on barbiturates (Stevenson and Turnbul1, 1970; Wahstrom, 1971) and decerebration or lesions of the septal area (Seguin and Stavraky, 1957; Harvey et al., 1964).

The alteration in neuronal sensitivity can be defined as an altered pharmacological response of the neuronal tissue to similar drug concentrations. Alteration of pharmacological response due to changes in the metabolism of the drug or the rate of entry of the drug into brain is not included in this definition. 
The alteration in neuronal sensitivity to drugs could sometimes be therapeutically beneficial. However, undesirable response to a drug treatment because of alteration in neuronal sensitivity to drugs is not very uncommon either. A better understanding of the mechanisms underlying these changes may aid in the development of preventive methods to counteract undesirable effects induced either by a drug treatment or an environmental extreme.

It is now well accepted that GABA plays a role as a specific inhibitory transmitter in the mammalian CNS (Davidoff, 1972; Ehinger and Falck, 1971). GABA has also . been shown to have non-specific depressant action, when applied directly to the brain of mammals (Bindman et al., 1962). Further, of all the depressant amino-acids, GABA occurs in largest amounts and it is uniquely present in the nervous tissue (Roberts, 1956). By virtue of these characteristics, alteration of GABA levels in the neuronal environment may be expected to alter the threshold of brain neurons to drug induced narcosis. There are several points that support this suggestion. They are summarized as below:

1. Treatments like desipramine (Shah and Lal, 1971), sodium nitrite or hypoxia (Baumei et a1., 1971, 1970b) cause hypothermia and potentiate barbiturate induced narcosis at $22^{\circ} \mathrm{C}$ but have no such effect at $30^{\circ} \mathrm{C}$ ambient temperature. Shah and Lal (1971) noted the finding of oja et al. (1968) that hypothermia elevates the brain levels of GABA. 
2. Sodium nitrite induced potentiation of barbiturate narcosts was reversed by hyperbaric oxygen (OHP) (Baume1 et al., 1971), a treatment known to cause marked reduction in brain GABA (Wood et al., 1967).

3. Hypoxia increased brain GABA (Wood et al., 1968), which enhanced the depression of brain neurons so that barbiturate induced-narcosis was potentiated (Baumel et al., 1970b). Moreover, hypoxia antagonized convulsions induced by semicarbazide or methionine sulphoxamine (Baumel et a1., 1969a, 1969b), drugs known to decrease brain levels of GABA (Killam and Bain, 1967; Roberts and Frankel, 1951; Lamar and Sellinger, 1965).

This investigation was undertaken to investigate the correlation between alteration in brain sensitivity to barbiturates and changes in brain GABA-1eve1s.

Based upon the hypothesis, the predictions which were undertaken for testing are:

1. That brain GABA-levels will be elevated by a variety of conditions known to increase the CNS sensitivity to barbiturates, these conditions will include:

a) exposure to hypobaric hypoxia

b) septal lesions

c) treatment with desipramirie, sodium nitrite or pargyline

2. That brain levels of GABA will be decreased by conditions known to lower the CNS sensitivity to barbiturates, these conditions will include: 
a) social deprivation

b) abrupt withdrawal following chronic barbiturate or alcohol administration

It was therefore undertaken to subject the animals to all of the aforementioned conditions or treatments and then measure their brain GABA-levels, in order to estab1ish that alteration of GABA-levels in the neuronal environment will alter the threshold of brain neurons to drug induced depression. 


\section{LITERATURE SURVEY}

\section{GABA}

Gamma-aminobutyric acid first appeared in the 1iterature in 1883 when the synthesis of a compound named "piperidinsaure" was reported (Baxter, 1970). But its presence in neurological tissue was not recognized until 1950 (Roberts and Franke1, 1950; Awapara et a1., 1950; Udenfriend, 1950). High levels of GABA are found in the peripheral nerves of crustaceans and in the central nervous system-brain, spinal cord and retina- of vertebrates.

In the central nervous system of mammals the "GABA shunt" (Figure 1) represents an alternate pathway in the portion of the tricarboxylic acid cycle that leads from alpha-keto glutarate to succinate. The carbon chain of alpha-keto glutarate can be converted via glutamic acid and GABA to succinate and $\mathrm{CO}_{2}$ (Baxter, 1970). The "GABA shunt" involves three enzymes, namely, glutamic acid decarboxylase (GAD), gamma-amino butyric acid-alpha-keto glutaric acid transaminase (GABA-T) and succinic semialdehyde dehydrogenase (SSA-D) (Roberts and Kuriyama, 1968). The close correlation between the level of GAD and GABA, in almost all areas of brain tested, suggest that GAD is the only significant enzymatic pathway leading to GABA in nerve tissue (Baxter, 19\%0). The major pathway of GABA 


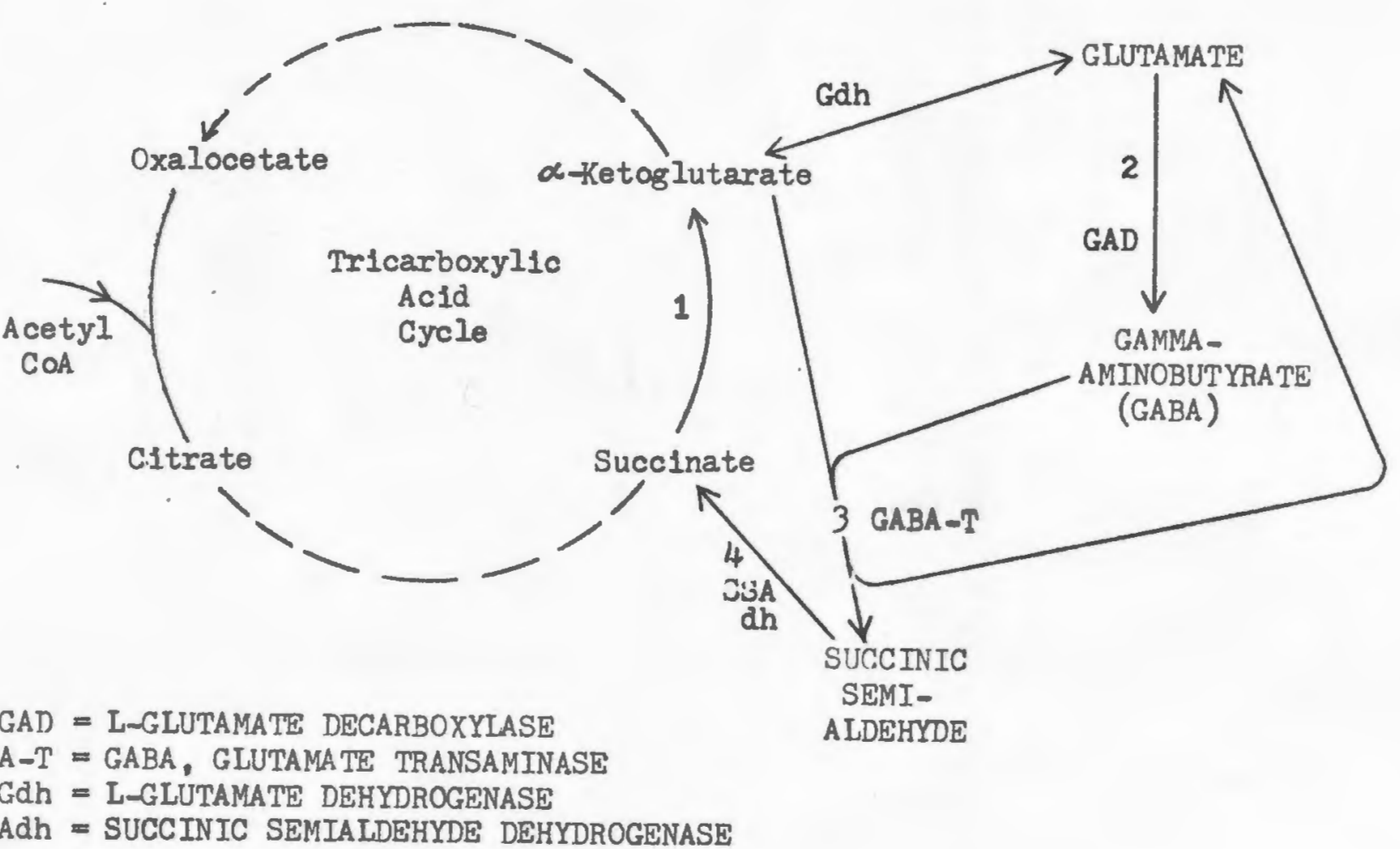

Figure 1. GAMMA-AMINOBUTYRIC ACID SHUNT. Pathways 2-4 represent the "GABA shunt" around pathway 1 of the tricarboxylic acid cycle. 
degradation is via transamination with alpha-keto glutarate to form glutamate and succinic semialdehyde, GABA-T has been shown to be involved in this reaction (Baxter and Roberts, 1958).

The enzyme L-glutamic acid decarboxylase (GAD) is found only in the central nervous system, largely in gray matter and most highly concentrated in nerve endings (Balazs et al., 1966; Salganicoff and DeRobertis, 1965). On the other hand, GABA-alpha-keto glutarate transaminase (GABA-T) is found in high concentrations in the cytoplasmic constituent of the gray matter (Roberts and Kuriyama, 1968). Both GAD and GABA-T are vitamin ${ }_{6} 6$ dependent enzymes (Baxter, 1970).

GABA as a Spreific Inhibitory Iransmitter and a Non-Specific Depressant Substance

GABA was established as an inhibitory transmitter at the crustacean neuromuscular junction several years ago (Kravitz et a1., 1965; 0tsuka et a1., 1966). Since then, evidence for GABA as a neurotrarsmitter in mammalian central nervous system has rapidly grown. At present, GABA appears to be an important inhibitory transmitter in mammalian CNS.

\section{GABA in Crustacean Neuromuscular Junction:}

Inhibitory neurons of the lobster contain a large amount of GABA; its concentration in inhibitory axons is about 100 times higher than that in excitatory axons 
(Kravitz et al., 1965). There is a remarkable parallel between the action of GABA on crayfish neuromuscular junction and that of neural inhibitory transmitter. For instance, both actions are antagonized by picrotoxin (Takeuchi and Takeuchi, 1965). Finally, it has been shown that GABA is . released from inhibitory nerves of the lobster in response to stimulation (otsuka et al., 1966).

\section{GABA in Mammalian Brain}

The depressant effects of GABA on the mammalian CNS have also been intensively studied and efficiently demonstrated in various laboratories. For example, the rapid and reversible depressant effects of GABA on electrical activity in the cerebral cortex were demonstrated by Iwama and Jasper (1957) and by Purpura et al. (1957). A depressant action of GABA on cortical neurons was also demonstrated in the rat (Mahnke and Ward, 1960) ana in surgical1y isolated (main circulation intact) cerebral cortex in the dog (Rech and Domino, 1960). Several other reports indicate that GABA, when applied directly to the brain of mammals, has a non-specific depressant action (Curtis and Watkins, 1960; Bhargava and Srivastava, 1964).

Particularly good evidence for GABA as an inhibitory neurotransmitter has been obtained in several areas of the mammalian brain, e.g., in cortical neurons (Krnjevic and Schwartz, 1967), Deiter's neurons (Obata et al., 1967; otsuka, 1972) and cuneate nucleus of the brain stem (Galindo 
et al., 1967). Recent reports by Davidoff (1972) and

Ehinger and Falck (1971) further support the possibility that GABA is an inhibitory transmitter in the spinal-cord and the brain.

Besides GABA, other inhibitory amino acids are also present in the brain, namely taurine, B-alanine, glycine and alanine (Tallan et al., 1954), hypotaurine (Bergeret and Chatagne, 1954) and Euanidini-acetic acid (Pisano and Udenfriend, 1958). Nevertheless, of all the depressant amino acids, GABA occurs in largest amounts; moreover, it occurs uniquely in nervous tissue (Roberts, 1956).

\section{GABA and Convulsions}

Wolfe and Elliott (1962) have reviewed the evidence for the role of GABA in convulsions under a variety of conditions. Since then, many correlative studies have been done, which can be summarized as follows:

1. intravenous or intraperitoneal GABA protected against drug-induced convulsions in monkeys (Kopeloff and Chusid, 1965).

2. intracisternal GABA suppressed seizures induced by intracisternal L-glutamate and pyridoxal-5-phosphate (Wiechert ard Herbst, 1966).

3. intravenous GABA produced sleep in chicks before the development of the blood-brain barrier and protected against pentylenetetrazole induced convulsions in 1day-old chicks (Kobrin and Seifter, 1966). 
4. Topical GABA inhibited the spontaneous epileptiform activity and diminished the amplitude of the surface negative wave of responses evoked by means of stimulation to the olfactory bulb (Guerrero-Figueroa et al., 1964).

5. The systemic administration of L-glutamic acid and amino oxyacetic acid ( $A O A)$, both known to elevate brain levels of GABA, protected animals against audiogenic seizures (Schlesinger et al., 1968).

6. GABA has also been observed to protect against audigenic seizures in mice, whether applied directly to the cortex (Ballantine, 1963), or administered systemically (Pasquini, et al., 1968).

7. exposure of animals to hypobaric oxygen (OHP) decreased brain GABA and produced convulsions (Wood et al., 1963). GABA administration protected these animals against convulsions (Wood et al., 1963).

\section{ACUTE HYPOXIA}

The term "hypoxia" means decreased availability of oxygen to the cells of the body. This condition may be caused by pulmonary disease (Oswald and Fry, 1962), circulatory insufficiency (Finley et al., 1962), anemias and tissue edema (Van Liere and Stickney, 1963). A common form of hypoxia encountered by aviators, astronauts and others working at high altitudes or in controlled gaseous environments is inadequate oxygenation of lungs due to a deficiency 
of oxygen in the atmosphere.

Hypoxia Due to Reduced Barometric Pressure

The total pressure of all gases in the air (barometric pressure) decreases as one ascends to higher altitudes. At sea level or normal room atmosphere, barometric pressure averages $760 \mathrm{~mm} \mathrm{Hg}$ and the pressure contributed by oxygen to the total pressure (partial pressure, $\mathrm{pO}_{2}$ ) is $159 \mathrm{~mm} \mathrm{Hg}$. Since oxygen remains at slightly less than $21 \%$ of the total gaseous atmosphere, the $\mathrm{pO}_{2}$ will decrease with corresponding decreases in total barometric pressure. Thus at $10,000 \mathrm{ft}$. barometric pressure $=523 \mathrm{~mm} \mathrm{Hg}$ and $\mathrm{pO}_{2}=110 \mathrm{~mm} \mathrm{Hg}$, whereas at $19,000 \mathrm{ft}$. the barometric pressure is $365 \mathrm{~mm} \mathrm{Hg}$ and $\mathrm{pO}_{2}=76 \mathrm{~mm} \mathrm{Hg}$, equivalent to a $10 \%$ oxygen atmosphere at sea level (760 mm $\mathrm{Hg})$.

Up to an elevation of approximately $10,000 \mathrm{ft}$. the $\mathrm{pO}_{2}$ in the air is sufficient to maintain arterial oxygen saturation at about $90 \%$. However, above $10,000 \mathrm{ft}$. elevation, arterial oxygen saturation falls progressively to approximately $70 \%$ at $19,000 \mathrm{ft}$. and still lower at higher altitudes, severely reducing the supply of oxygen delivered by blood to the tissues (Folk, 1966).

\section{Hypoxia and Brain Sensitivity}

Baumel et al. (1969a; 1969b; 1969c; 1970b) have presented evidence that exposure of mice to hypoxia (364 mm $\mathrm{Hg}$, $\mathrm{pO}_{2}=76 \mathrm{~mm} \mathrm{Hg}$ ) increased the sensitivity of brain neurons to 
drug induced depression. The evidence can be summarized as follows; the hypoxic exposure:

1. at $22^{\circ} \mathrm{C}$ and $30^{\circ} \mathrm{C}$ ambient temperature, significantly increased the duration of parcosis due to barbital, pentobarbital, chloral hydrate and shortened the onset of narcosis due to barbital in mice.

2. at $22^{\circ} \mathrm{C}$ ambient temperature, significant $1 \mathrm{y}$ lowered pentobarbital whole-body levels at awakening in mice.

3. antagonized convulsions induced by, a) semicarbazide, methionine sulphoximine or m-fluorotyrosine, and b) intracerebral senicarbazide.

The hypoxic exposure at $22^{\circ} \mathrm{C}$ and $30^{\circ} \mathrm{C}$ ambient temperature, decreased absorption of Darbital- $\mathrm{c}^{14}$ from the site of injection but did not alter penetration of barbital-c ${ }^{14}$ into brain.

Baumel et al. (1970) also reported that the exposure of the animals to hypoxia at $22^{\circ} \mathrm{C}$ ambient temperature resulted in significant reduction in body temperature and that this effect was abolished at $30^{\circ} \mathrm{C}$ ambient temperature.

Hypoxia and GABA

Exposure to hypoxia $\left(5-8 \% \mathrm{O}_{2}\right)$ for more than $10 \mathrm{~min}-$ utes has been shown to elevate brain GABA significantly in the mouse, hamster, rat, guinea pig and rabbit, with maximum elevation occurring at 60 minutes and the GABA falling off gradually thereafter (Wood, 1967; Wood et al., 1968). Wood has also suggested that GABA possibly plays a homeo- 
static role in brain metabolism in hypoxic condition (Wood, 1967).

\section{SEPTAL LESIONS}

Septal Lesions and Brain Sensitivity

Subcortical lesions may affect an animal's sensitivity to barbiturates. Heller et al. (1960) found that lesions in the septal area of the basal telencephelon in rats caused a 3-to-4 fold increase in both thiopental and barbital induced narcosis as compared with normal controls. The septal 1esions also reduced the time for induction of narcosis by barbital by one-half (Harvey et al., 1964). This increase in barbiturate sensitivity has been shown to be specific to septal regions since lesions of comparable size in cortex and in caudate nucleus do not significantly alter barbiturate induced narcosis (Harvey et al., 1963). The increased sensitivity of the central nervous system to barbiturates could not be attributed to the effects of lesions on body weight, temperature regulation, drug wetabolism, adrenal function or total brain levels of the drug (Roth and Harvey, 1968).

\section{Erain Lesions and Chemical Changes}

Many of the lesion studies done in connection with barbiturate action have been reported to produce substantial decreases in brain. concentration of serotonin, norepinephrine and copanime (He1ser et al., 1962); Harvey et al., 
1963; Harvey, 1965; Simpson et al., 1967).

Harvey (1965) suggested that increase in sensitivity

to a drug after subcortical lesions (Septal or dorsomedial

tegmentum) may be due to the effects of the lesions on

chemical processes in the remaining portions of the brain which are both similar to and additive with the effects of the drug.

\section{DRUG TREATMENTS}

Sodium Nitrite

A great many substances such as nitrites, phenacetin, acetanilide, sulfanilamide, nitrobenzene and analine can produce mathemoglobinemia (Bodansky, 1951). Methemoglobin cannot carry oxygen, so the delivery of oxygen to the tissues is impaired (Darling and Roughton, 1942).

\section{Sodium Nitrite and Brain Sensitivity}

Baumel et al., (1971) have reported evidence that pretreatment of animals with sodium nitrite enhances the depression of brain neurons. The evidence can be summarized as follows; sodium nitrite pretreatment:

1. at $22^{\circ} \mathrm{C}$ ambient temperature, markedly increased the duration of narcosis due to barbital or hexobarbital, shortened the onset of narcosis due to barbital and produced hypothermia in mice. However, at $30^{\circ} \mathrm{C}$ ambient temperature the hypothermic effect was abolished as was the increase in duration narcosis due to barbital. 
2. significantly lowered the hexobarbital whole-body levels in mice at awakening.

3. protected mice against intracerebral semicarbazide induced convulsions.

4. induced potentiation of barbiturate narcosis was prevented by hyperbaric oxygen (OHP), a treatment known to reduce brain levels of GABA (Wood, et al.. 1963).

Sodium nitrite reduced absorption of barbital-c $\mathrm{c}^{14}$ from the site of injection but did not alter its penetration into brain.

\section{Desipramine}

Like many drugs, desipramine (DMI) and its parent substance imipramine, interact with other compounds in a complex manner. These two tricyclic anti-depressants enhance the action of amphetamine (Carlton, 1961) and tremorine (Sjoquist and Gillette, 1965); they potentiate hypothermia due to infusion of $\mathrm{NE}$, epinephrine or isoprenaline (Jori and Garrattini, 1965) and imipramine prevents or counteracts hypothermia induced by reserpine (Garrattini and Jori, 1967).

\section{DMI and Brain Sensitivity}

Shah and Lal (1971) have presented evidence that pretreatment of mice with DMI lowers neuronal excitability. The evidence can be summarized as follows; DMI pretreatment: 
1. at $23^{\circ} \mathrm{C}$ ambient temperature, sienificantly potentiated narcosis due to barbital or hexobarbital, shortened the onset of narcosis due to barbital and produced a significant reduction in body temperature. However, at $30^{\circ} \mathrm{C}$ ambient temperature the hypothermic effect was abolished as was the potentiation of barbital-induced narcosis.

2. significantly lowered the hexobarbital whole-body levels at awakening.

3. did not alter rate of penetration of barbital into brain.

\section{SOCIAL DEPRIVATICN}

Depriving an organism of social interactions removes the normal stimuli obtained from group contacts and results in changes in the behavior and physiologic responses of the organism.

Prolonged social deprivation has been observed to elicit intense aggression in male mice (Yen et al., 1959). These animals possess a heightened neuroexcitability which manifests itself in hyperreactivity to physical stimuli (Kimbre11, 1967; King eti al., 1955).

Physiologic alterations in socially deprived animals include a smaller adrenal weight (Valzelli and Garrattini, 1968), higher plasma corticosterone (Sigg, 1969), decreased body weight (Hatch et al., 1965) and decreased turnover of brain serotonin (Giacalone et al., 1968). 
The levels of brain GABA in the dog have also been correlated with social deprivation (Agrawal et al., 1967).

\section{Social Deprivation and Brain Sensitivity}

Baumel et al. (1970) have presented evidence that prolonged social deprivation of mice raised arousal levels such that their susceptibility to CNS depressants was reduced. The evidence can be summarized as follows; social deprivation of mice for 5 weeks:

1. significantly reduced duration of narcosis due to barbital, pentobarbital or hexobarbital but did not alter onset of barbital-induced narcosis, suggesting that the permeability of drugs into the CNS was not changed.

2. significantly increased hexobarbital whole-body levels at awakening.

\section{DRUG WITHDRAWAL}

\section{Barbiturate}

The chronic administration of barbiturates has been reported to produce tolerance and physical dependence in humans (Isbe11, 1950) and in common laboratory animals (Crossland and Lecnard, 1963; Essig, 1966; Norton, 1970; Jaffe and Sharpless, 1965).

Abrupt discontinuation of barbiturates, subsequent to its chronic administration in large doses, resulted in spontaneous tonic-clonic convulsions in rats (Essig, 1966). 
The abstinence convulsions, a reliable index of the barbiturate abstinence syndrome, have been reproduced in several animal species (Essig, 1967). Wahlstrom (1971) reported that chronic barbital administration and withdranal increased the hexobarbital thresholds ("the quantity of intravenously infused hexobarbital needed to produce a burst suppression of 1 second or more in the EEG") in rats by more than $45 \%$ as compared to a pre-experimental average. Since the aforementioned thresholds wexe not influenced by an increase in metabolism (Wahlstrom, 1968), the data suggest that an alteration in neuronal sensitivity to barbiturates had taken place.

Since levels of brain GABA have been correlated with convulsions under a variety of conditions. (Essig, 1968), suggested that the convulsions induced by barbiturate withdrawal could be due to reduction in brain levels of GABA. This was further supported by the fact that amino-oxyacetic acid (AOAA), a compound known to elevate brain GABA (Wallach, 1961), protected rats and dogs against barbiturate withdrawal induced convulsions (Essig, 1968).

\section{Alcohol (Ethanol)}

Chronic administration of alcohol has been reported to produce tolerance and physical dependence in humans (Isbell et al., 1955) and in common laboratory animals (Goldstein and Pal, 1971; Freund, 1969; Essig and Lam, 1968). Abrupt alcohol withdrawal after chronic administra- 
tion has been shown to result in a typical abstinence syndrome, which is characterized by tremors, generalized tonic-clonic convulsions and a lowering of the threshold for electroconvulsive seizures (Freund, 1969; Essig and Lam, 1968; McQuarrie and Fingl, 1958). Freund and Walker (1971) found that $\mathrm{C} 57 \mathrm{BL} / 6 \mathrm{~J}$ mice, a strain genetically resistant to the induction of audiogenic seizures, could become highly susceptible to audiogenic seizures upon abrupt withdrawal of ethanol after its chronic administration. Several hypotheses have been proposed to explain the mechanism of convulsions occurring during withdrawal from addictive drugs (Mendelson, 1970).

Animal models for alcohol dependence have only very recently been developed. Essig and Lam (1968), Fllis and Pick (1969) and. Freund (1969) have shown that development of physical dependence in animals is a surprisingly rapid process, as compared with the slow progress of alcoholism in man. The shortest reported times for producing withdrawal reactions are about 2 weeks in dogs and monkeys and 4 days in mice. The recent report by Goldstein and Pal (19\%1) indicate that, it is possible to produce alcohol dependence in mice by maintaining intoxicating blood levels of ethanol for two days. They used pyrazole, an inhibitor of alcohol elimination in vivo, and housed animals in an atmosphere of ethanol vapour.

The assumed role of GABA as an inhibitory transmitter has elicited interest in possible effects of ethanol on 
levels and metabolism of GABA. Ethanol has beer reported to raise the concentration of GABA, glutamate and aspartate, and to decrease glutamine, in the brains of rats in vivo (Hakkinen ans Kulonen, 1961) and electrically stimulated cerebral cortex tissue in vitro (Hakkinen et al., 1963). An acute intoxicating dose of ethanol, to rats, has been reported to decrease the concentration of GABA in cerebral hemispheres and in cerebellum (Gorden, 1967). In the brains of rats given $15 \%$ alcohol as sole fluid for 23 days, bound GABA was slightly lowered whereas free GABA was not changed (Hagen, 1967).

\section{Alcohol and Pyrazole}

Pyrazole inhibits the metabolism of ethanol both in vitro and in vivo. In 1963, Theorell and Yonetani reported that pyrazole inhibited liver alcohol dehydrogenase by formation of a ternary complex with $A D H$ and nicotinamideadenine dinucleotide (NAD). Lester et a1. (1968) and Goldberg and Rydberg (1969) showed that pyrazole inhibited ethanol metabolism in rats as evidenced by the persistence of high blood alcohol concentrations. In the former study, it was reported that pyrazcle and 4-substituted pyrazoles inhibited ethanol metabolism, while substitution in any other position did not produce a similar inhibjtion. More recently, two investigations (Bustos et al., 1970; Morgan and DiLuzio, 1970) appeared which dealt with the induction of fatty livers in animals treated with pyrazole-etinanol. 
Although the principal findings of these studies were distinctly controversial, the investigators were in agreement with regard to one important observation: the concentrations of blood ethanol in rats treated with pyrazole-ethanol persisted at a high level for as long as 16-20 hr, thus indicating a pyrazole-induced inhibition of ethanol metabolism. 


\section{EXPERIMENTAL}

\section{Anima 1s:}

Swiss albino, random bred male mice weighing 25-35 g and Sprague-Dawley albino, random bred male rats (Charles River Farms, Wilmington, Mass.) weighing 150-200 g were used. They were housed in animal quarters maintained at $21-23^{\circ} \mathrm{C}$ with room lights alternated on a $12 \mathrm{~h}$ light-dark cycle. Food and water were available ad libitum up to one hour before each experiment. Animals were used not earlier than one week after receipt from the supplier.

\section{Materials:}

Analytical reagent grade chemicals or equivalent were used throughout the study. Co-factors were purchasod from P-L Biochemicals Inc., Milwaukee, Wisc. The drugs and the enzymes used in this investigation were obtained from their respective manufacturers.

\section{Hypobaric Chambers:}

The hypobaric chambers (Figure 2) utilized room air and consisted of four plexiglass desiccators (Internal diameter 10", height 14", Ace Glass Inc.) connected in parallel via $1 / 2$ " rubber tubing to a vacuum pump ( $1 / 2 \mathrm{~h} . \mathrm{p}$., Gélman Instruments) through a manifold consisting of $1 / 4$ " copper pipe. The degree and rate of reduction in ambient pressure within the chambers was controlled by a central 


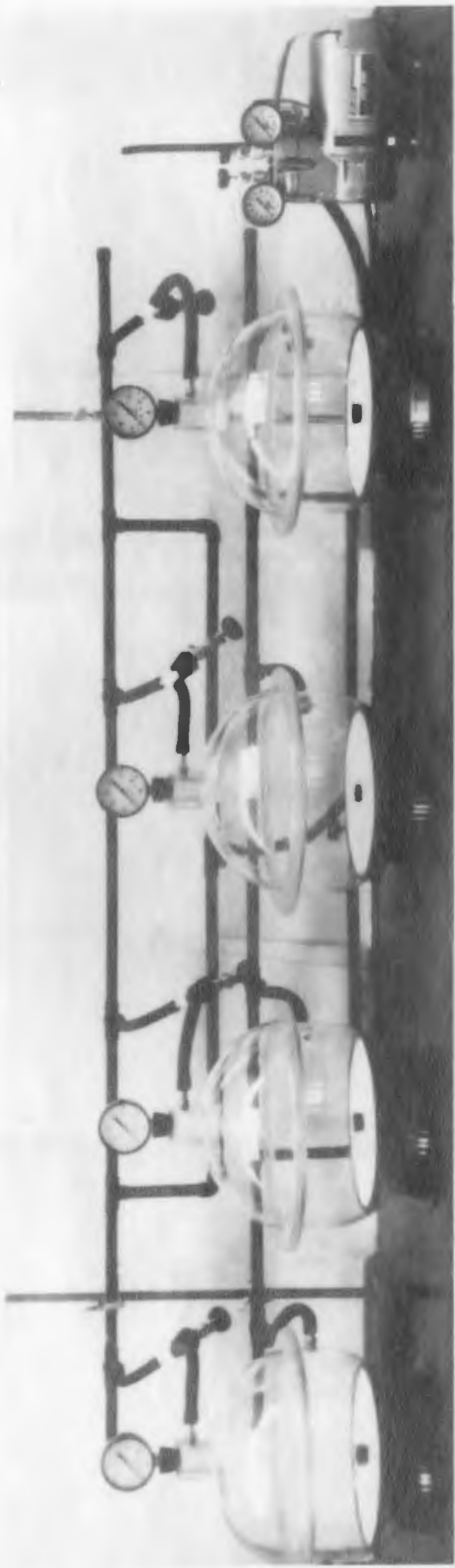

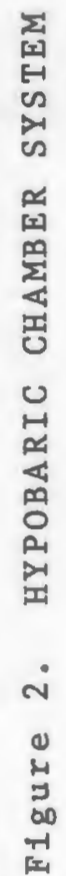


needle valve attached to the air intake manifold. The barometric pressure within the system was monitored by vacuum gauges on individual chambers and mercury manometer attached to the end chamber. Separate needle valves placed along the system permitted recompression of individual chambers independent of the other units.

Decreasing barometric pressure within the chambers to $364 \mathrm{~mm} \mathrm{Hg}\left(\mathrm{pO}_{2}=76 \mathrm{~mm} \mathrm{Hg}\right.$, equivalent to a $10 \%$ oxygen atmosphere at sea level) resulted in room air entering the system at approximately 91 iters/min which was assumed to be adequate for continuous removal of expired carbon dioxide, and prevention of excess moisture condensation within the chambers. Under these conditions, the temperature within the chambers was maintained within $1^{\circ}$ of the ambient temperature.

Exposure to Hypoxia:

The animals were placed, in pairs, in each of the four chambers which were then decompressed in a 10 minute period to $364 \mathrm{~mm} \mathrm{Hg}\left(\mathrm{pO}_{2}=76 \mathrm{~mm} \mathrm{Hg}\right.$, equivalent to a $10 \%$ oxygen atmosphere at sea level). Control mice were run concurrently in identical chambers open to room air. One group of mice was exposed continually to hypobaric hypoxia for 30 minutes and the other group was exposed for 60 minutes. The animals were then removed from the hypoxia chambers at the end of 30 or 60 minutes and were immediately frozen in 1iquid nitrogen. The experiments were done at 22 and $30^{\circ} \mathrm{C}$ ambient temperature in a constant temperature environmental chamber. Brain Lesioning:

Bilateral electrolytic lesions were produced in 
175-200 g male albino rats of the Sprague-Dawley strain, by means of David Kopf stereotaxic apparatus. The method was that of Zuromski et al. (1972). The subjects were anaesthetized with Nembutal (40 mg/ kg) supplemented by $10 c a 1$ application of Xylocaine. Bilateral septal lesions were produced using 2 ma anodal current for $20 \mathrm{sec}$ through the uninsulated tip of a stainless-steel pin. The stereotaxic instrument with a modified head-holder which held the head level was used to position the electrode, $1.0 \mathrm{~mm}$ anterior to bregma, $2.5 \mathrm{~mm}$ lateral from the midline, $5.5 \mathrm{~mm}$ deep (from tine surface of the cortex), and $25^{\circ}$ toward the midline. Shamoperated controls and normal controls were also included. In the sham-operation the animal was anaesthetized, placed in the stereotaxic apparatus and the skull drilled but dura spared. All animals were given 25,000 units of procaine penicillin post-operatively. All animals were housed individually immediately after the operation and then housed two per cage on the seventh postoperative day until termination of the experiment. Barbital induced narcosis was measured in order to confirm location of the septal lesions (see Harvey et al. 1964).

Measurement of Drug-Induced Narcosis:

Duration of narcosis was taken as the interval between the loss and the regain of righting reflex, the end point of which was determined according to wenzel and Lal (1959) using two rightings within 30 seconds. The interval between injection of the drug and loss of righting reflex 
was designated as onset of narcosis (induction time). Barbjtal was injected intraperitoneally as the sodium salt in distilled water. Determination of duration of barbital narcosis and induction time were done as described above.

\section{Social Deprivation:}

Mice weighing 18-20 gm were housed either 1 to a cage or 10 to a cage in stainless steel cages $\left(9.5^{\prime \prime} \times 7^{\prime \prime} \times 7^{\prime \prime}\right)$ with wire mesh on fronts and bottoms. Solid walls on the remaining 3 sides reduced visual or tactile contacts of the isolated mice with other animals. Animals were not handled or removed from their cages during the deprivation period but were kept clean by changing the bottom pans regularly. The mice were subject to all daily noises of the animal room. Ambient temperature was maintained at $21-23^{\circ} \mathrm{C}$ and room lights alternated on a $12 \mathrm{~h}$ light-dark cycle.

Chronic Phenobarbital Administration and Withdrawal:

The fluid intake of mice was restricted to increasing concentrations of phenobarbital in drinking water. Their initial dose was $50 \mathrm{mg} / \mathrm{kg} / \mathrm{day}$ and was increased week1y until they received $400 \mathrm{mg} / \mathrm{kg} /$ day. Phenobarbital solution also contained $0.2 \mathrm{mg} / \mathrm{ml}$ saccharin to mask the bitter taste of the barbiturate. Control animals received 0.2 $\mathrm{mg} / \mathrm{ml}$ of saccharin in drinking water for four weeks. This method was originally reported by Crossland and Leonard $(1963)$

During the experiment six mice were housed per cage. Fresh phenobarbital solution (100 ml) was given every day 
and total amount of the solution consumed by a group of six animals per day was recorded during the entire period of four weeks.

At the end of four weeks of phenobarbital, the drug administration was discontinued. The animals were given drinking water only. After 24 hours, elght randomly selected experimental animals were exposed to an auditory stimulus (100 dB for 30 seconds). Mice showing convulsions within 30 seconds were immediately frozen in liquid nitrogen and were stored at $-40^{\circ} \mathrm{C}$. The same procedure was followed for 48 and 120 hour withdrawa animals except that, some of the 48 hour and all of the 120 hour withdrawn animals did not exhibit any CNS hyperexcitability (convulsions). Further, a group of 24 hour withdrawn animals was sacxificed without any prior exposure to the auditory stimulus. Control animals were exposed to the stimulus for 30 seconds before sacrifice.

\section{Ethanol Vapour-Chamber:}

The ethanol vapour-chamber (Figure 3) consisted of a flat bottom, cylindrical glass jar placed horizontally on a wooden platform. It contained a perforated floor, drinking water and food pellets. The open end of the jar was closed by a wooden frame with a circular window ( 5 " diameter) for the introduction of the animals and was fitted with a rubber stopper (2" diameter) having four holes. The rubber stopper was fitted with two inlets (one for air and the other one for ethanol) and outiet tubings and a thermom- 


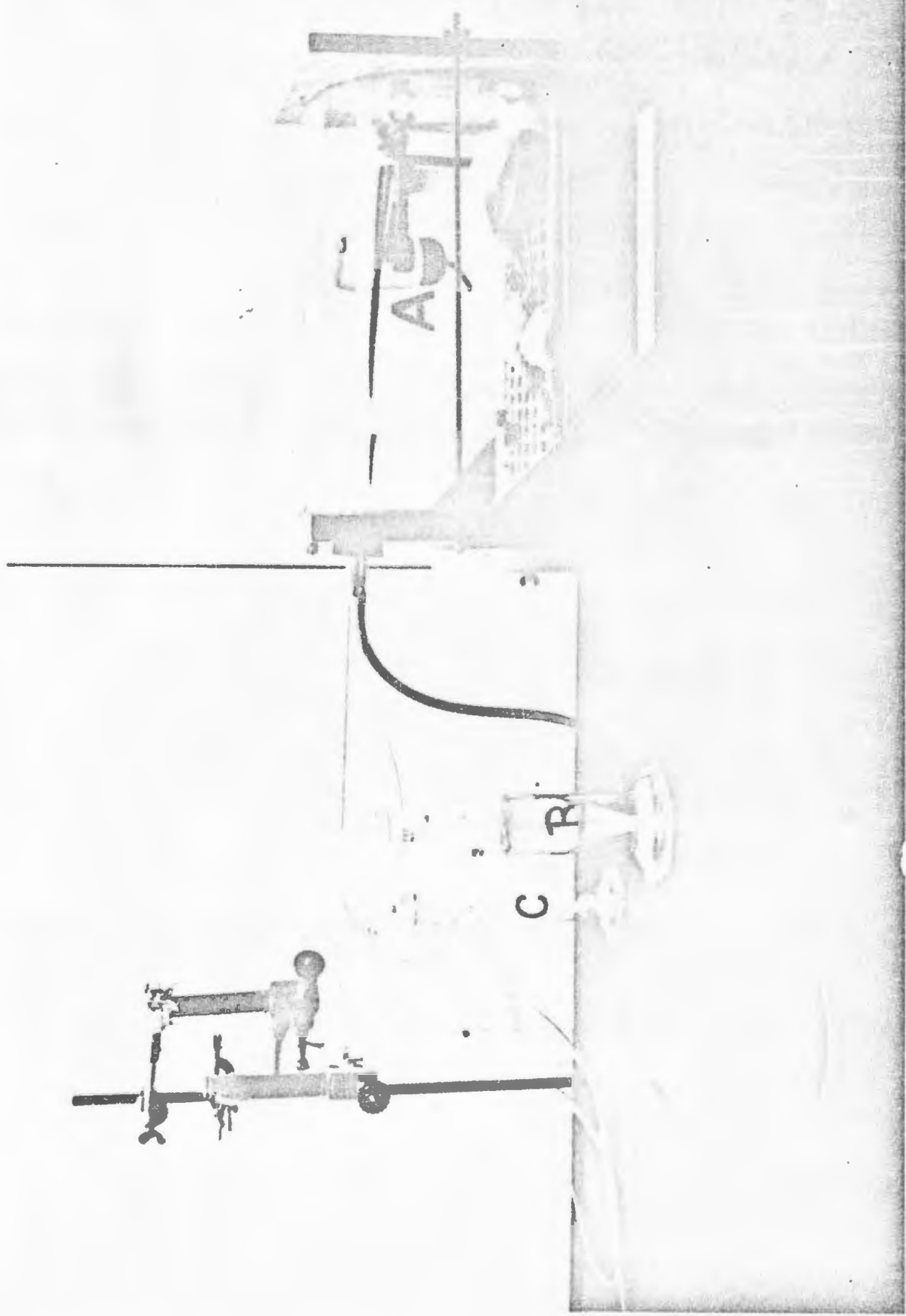

告 
eter. Air and alcohol inflows were regulated by two separate flow meters (Hoke Inc., Cresski11, N.J.).

\section{Determination of Ethanol Vapour-Concentration:}

The enzymatic method of Lundquist (1959) was used for the determination. A sample of chamber air, $1 \mathrm{ml}$, was withdrawn in Hamilton air-tight syringe (Hamilton Company Inc., Ca1.). The air sample was then injected through the airtight rubber cork into the head space of a vial containing $5 \mathrm{ml}(4.8 \mathrm{ml}$ buffer $+\mathrm{C.1} \mathrm{ml}$ enzyme $+0.1 \mathrm{ml} \mathrm{N.AD})$ of the reaction mixture used for the deternination of ethanol in blood. The reaction was allowed to proceed for $60 \mathrm{~min}$ at room temperature and the absorption was measured at $340 \mathrm{mu}$. The optical didity, after subtraction of a blank value (1 ml of. rooni aix), ras used in the following formula to get mg of ethanol/1iter of chamber air.

$$
\frac{\text { Sample oD }}{\text { Standard OD }(2 \mathrm{mg} / \mathrm{ml})} \times 39.2=\mathrm{mg} \text { ethanol/liter of } \underset{\text { air }}{\text { chamber }}
$$

The standard analysis was made by addition of $100 \mathrm{ul}$ of the ethanol standard solution containing $1,1.5$ and $2 \mathrm{mg}$ of ethanol per ml of distilled water. Figure 4 demonstrates the relationship between air flow (liters/minute) and chamber air-ethanol concentration (mg/liter).

Determination of Blood Ethanol-levels:

The assay procedure was that of Lundquist (1959). Mice were removed from the chamber and were sacrificed by cervical dislocation. About 150 ul blood was withoiram from 


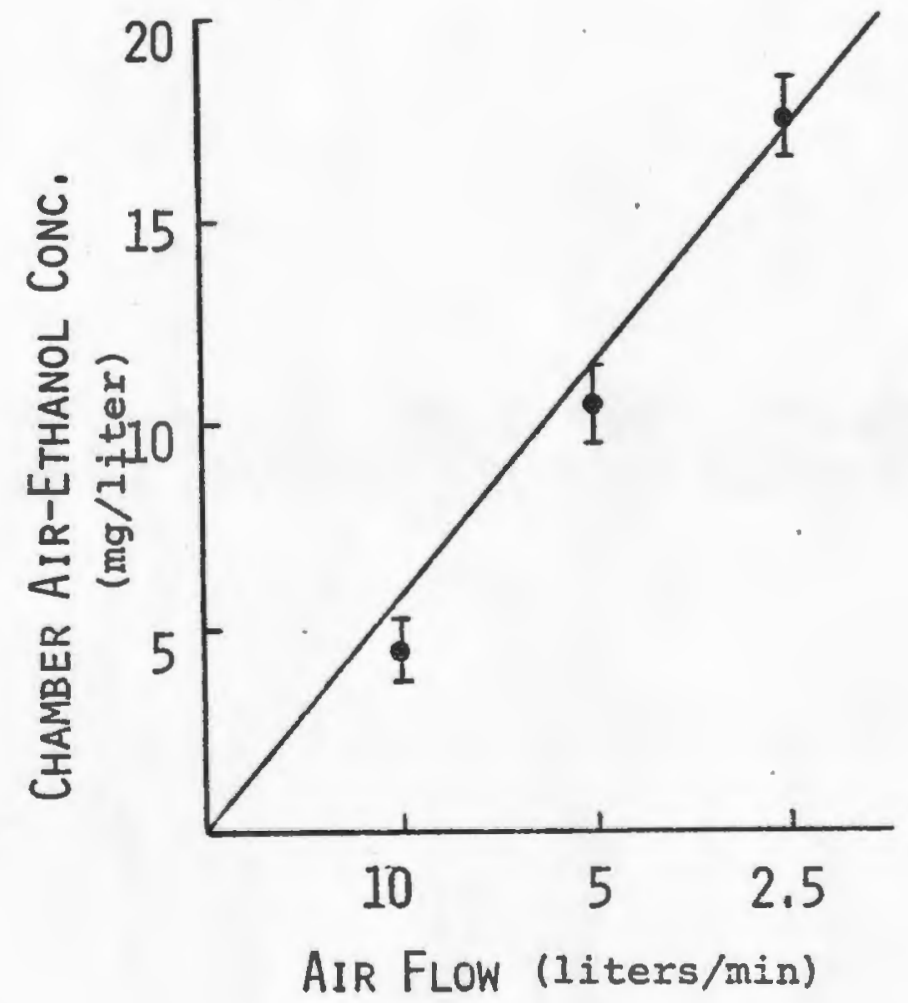

Figure 4. RELATIONSHIP BETWEEN AIR-FLOW (1iters/min) AND CHAMBER AIR-ETHANOL CONCENTRATION (mg/1iter). An airethanol mixture was obtained by mixing two streams of air: one directly to the chamber at a rate of $2.5,5$ or 10 liters/min and the other bubbling through absolute ethanol (Reagent Quality, U.S.P.) contained in a glass jar to the chamber at a flow rate of 0.75 liters/min (which was kept constant). Each point represents the mean \pm S.E. of three determinations. 
the heart with a tuberculin syringe. The sample containing $100 \mathrm{ul}$ of blood was then deprotenized by means of perchloric acid ( 4 volume, $3.4 \%$ ). The supernatant obtained after centrifugation at $2500 \mathrm{rpm}$ for $10 \mathrm{~min}$ was used directly for analysis. The supermatant (100 崖) was added to $4.8 \mathrm{~m} 1$ of a buffer containing pyrophosphate and semicarbzide ${ }^{1}$ at pH 8.6-8.7, together with $100 \mathrm{ul}$ of $1.3 \% \mathrm{NAD}^{2}$ solution. The enzymatic reaction was started by addition of 50 ul of crystalline yeast alcohol dehydrogenase suspension. ${ }^{3}$ The reaction was allowed to proceed for 60 min at room temperature and the absorption was measured at $340 \mathrm{mu}$. The optical density, after subtraction of a non-ethanol blanic value, was proportioral to the concentration of ethyl alcohol in blood. The standard analysis was made by addition of 1.00 ul of absolute ethanol standard solution containing $1,1.5$, 2 and $2.5 \mathrm{mg}$ of ethanol per ml of distilled water. Figure 5 demonstrates the standard curve for quantitative determination of ethanol by the enzymatic method of Lundquist (1959).

${ }^{1}$ Prepared by dissolving $10 \mathrm{~g}$ of sodium pyrophosphate, $2.5 \mathrm{~g}$ of semicarbazide hydrochloride, $0.5 \mathrm{~g}$ of glycine and $10 \mathrm{mi}$ of $2 \mathrm{~N} \mathrm{NaOH}$ in sufficient water. The final volume was adjusted to $300 \mathrm{ml}$ with distilled water and the $\mathrm{pH}$ was adjusted to $8 \cdot 6-8 \cdot 7$.

${ }^{2}$ Nicotinamide-adenine dinucleotide.

$330 \mathrm{mg}$ of the enzyme was suspended in $1 \mathrm{ml}$ of saturated solution of ammoniun sulfate. 


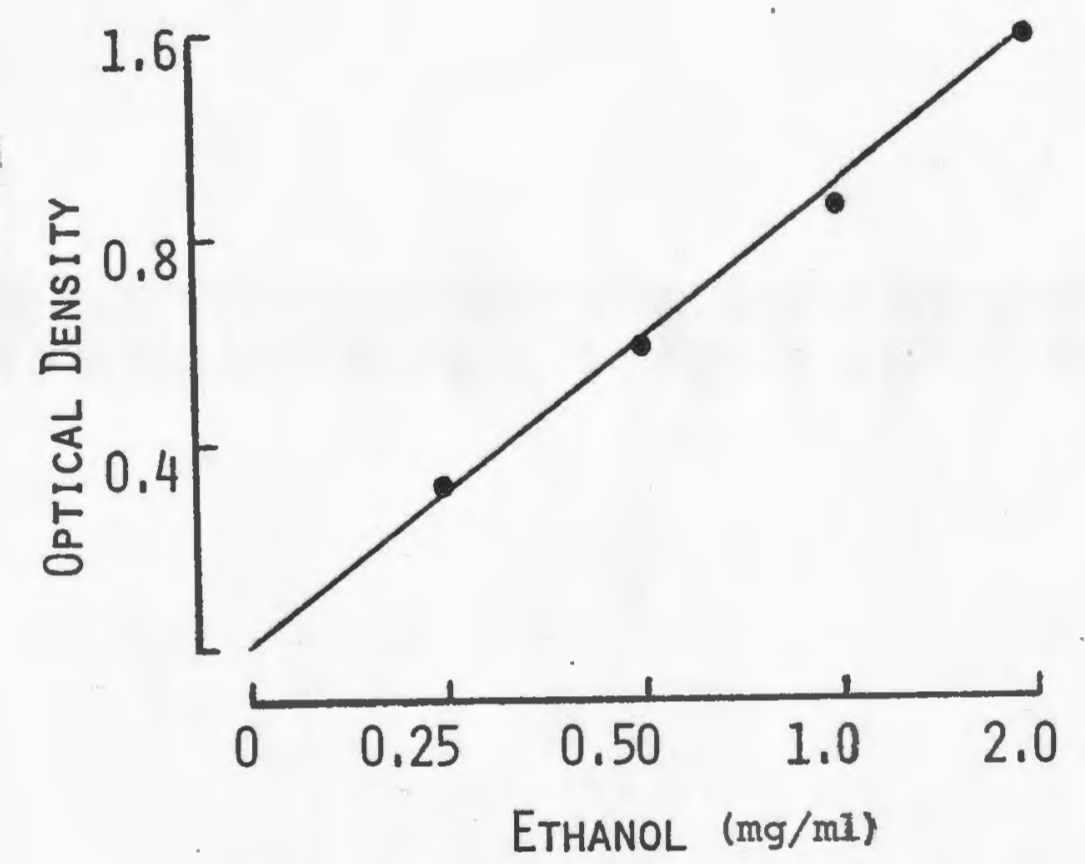

Figure 5. STANDARD CURVE FOR QUANTITATIVE DETERMINATION OF ETHANOL IN BLOOD. The enzymatic method of Lundquist (1959) was used. Pure yeast alcohol dehydrogenase (30 $\mathrm{mg} / \mathrm{ml}), 0.05 \mathrm{ml}$, and $1.3 \% \mathrm{NAD}(0.1 \mathrm{ml})$ was added to the ethanol solution containing semicarbazide-glycine buffer, pH-8:6-8.7. After 60 minutes at room temperature the mixtures were read at $340 \mathrm{mu}$. 


\section{Chronic Ethanol Intoxication and Withdrawal:}

The animals were exposed continually for 96 hours in the ethanol vapour-charaber (Figure 3) to an.air-ethanol mixture obtained by mixing two streams of air: One directly to the chamber at a rate of 5 liters/minute and the other bubbling through absolute ethyl ascohol (U.S.P.) contained in a glass jar to the chamber at a flow rate of 0.7511 ters/ minute. With these flow rates the chamber air-ethanol concentration remained at $10 \mathrm{mg} / 1$ iver (Figure 4). The mice were removed from the chambex twice a day for about 25 minutes in order to weigh them and to inject pyrazole (once daily). Pyrazole vas given to obtain stable blood ethanol levels; it has been shown to inhibit the metabolism of ethanol both in vitro and in vivo (Theorell et al., 1969). The dose of pyrazole we used was, $0.5 \mathrm{mmole} / \mathrm{kg}(34 \mathrm{mg} / \mathrm{kg}$ ), i.p., given at $0,24,48$, and 78 hours during the exposure of mice to an air ethanol mixture.

The chamber air-ethanol concentration ( $10 \mathrm{mg} /$ liter), and the daily dose of pyrazole $(0.5 \mathrm{mmole} / \mathrm{kg})$ maintained the blood alcohol-levels of mice at 1.5 to $1.9 \mathrm{mg} / \mathrm{ml}$ for four days (Figure 6).

The mice were removed from the ethanol vapour-chamber 24 hours after their last dose (at 72 hours) of pyrazole. They were then observed almost continually for 12 hours, with scores of abstinence syndrome recorded hourly. Measurement of Gamma-Aminobutyric Acid:

The assay procedure was that of Graham and Aprison 


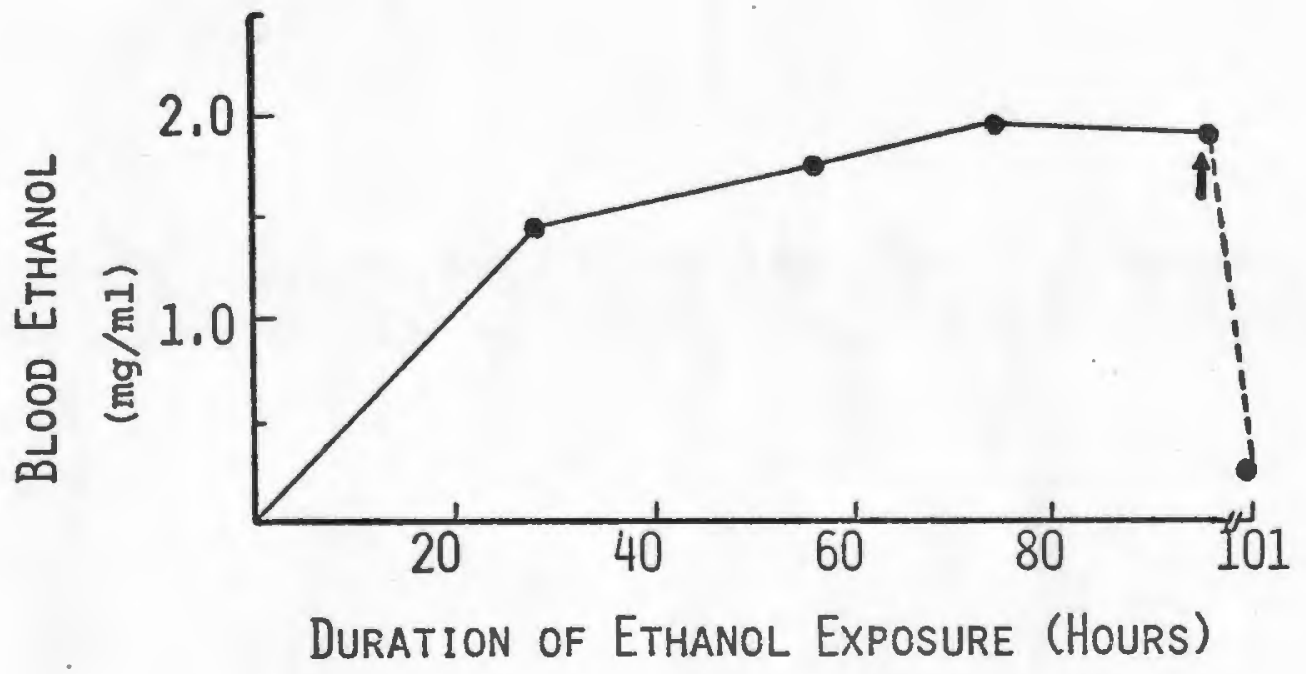

Figure 6. BLOOD ETHANOL CONCENTRATIONS DURING EXPOSURE TO ETHANOL VAPOUR. Each point represents the average blood ethanol-levels of two mice. They were exposed to ethanol vapour concentration of $10 \mathrm{mg} / 1$ iter for 96 hours. Pyrazole $(0.5 \mathrm{mmole} / \mathrm{kg})$ was injected at $0,24,48$ and 72 hours. Blood samples were taken for ethanol assay each afternoon before pyrazole was injected. $\uparrow$ indicate withdrawal (removal of the animals from the chamber). blood ethanol-levels dropped to $0.24 \mathrm{mg} / \mathrm{ml}$ in about 5 hours after withdrawal. 
(1966). Whole mouse or rat heads were frozen in liquid nitrogen and kept at $-40^{\circ} \mathrm{C}$ for $20-24$ hours. At the time of assay whole brains were rapidly removed (within 45 seconds), weighed and homogenized: a) a mouse brain in 20 volumes of ice-cold $75 \%(\mathrm{v} / \mathrm{v})$ ethanol or b) a rat brain in 4 volumes of 1ce-cold 75\% ethano1. Samples were then centrifuged at $5000 \mathrm{rpm}$ at $0^{\circ} \mathrm{C}$ for 15 minutes. The supernates were removed and stored at $4^{\circ} \mathrm{C}$ while the pellet was resuspended in 20 volume (for a mouse brain) or 4 volume (for a rat braira) of ice-cold $75 \%$ ethanol and centrifuged as above. Eoth supernate fractions were then combined and mixed thoroughly. Two $\mathrm{ml}$ samples (from a mouse brain supernate) ox $0.4 \mathrm{~m} 1$ samples (from a rat brain supernate) were added to sample vials and evaporated to dryness at $60^{\circ} \mathrm{C}$ in a water bath with constant air flow into each vial. Samples were kept at $-40^{\circ} \mathrm{C}$ for 24 hours at which time GABA was measured. The contents of each vial were suspended in 5 ml of water. Two ml of sample was shaken with an equal volume of chloroform and centrifuged in a clinical centrifuge (International Equipment Company) at 3500 rpm for 20 minutes.

The substrate solution contained $1.4 \mathrm{ml}$ pyrophosphete buffer $^{1}(0.1 \mathrm{M}, \mathrm{pH} 8.4), 0.2 \mathrm{ml} \mathrm{NADP}^{2}(0.005 \mathrm{M}$ in water),

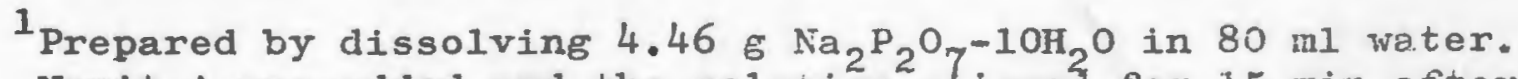
Norit-A was added and the solution stirred for 15 min after which the solution was filtered through Celite. The pH was adjusted to 8.4 with IN HCL and the volume adjusted to 100 ml. The buffer was stored in an amber bottle at $4^{\circ} \mathrm{C}$ are was prepared fresh 24 hour prior to each assay.

2 Nicotinamide-adenine dinucleotide phosphate.
} 
$0.2 \mathrm{ml}$ alpha-keotglutaric acid ( $0.1 \mathrm{M}$ in buffer), $0.2 \mathrm{~m} 1$ mercaptoethanol ( $0.06 \mathrm{M}$ in buffer) and $10 \mathrm{mg}$ GABase enzyme. Incubation mixtures contained $0.1 \mathrm{~m} 1$ brain sample, standard or water; $0.1 \mathrm{~m} 1$ pyrophosphate buffer and $0.04 \mathrm{ml}$ substrate solution. Tissue blanks were prepared in the same manner except that no GABase was added. Incubations were for 45 min at $37^{\circ} \mathrm{C}$ in a Dubnoff metabolic shaker. After incubation, $0.2 \mathrm{ml}$ alkaline phosphate ${ }^{1}$ was added to the tubes and mixed thoroughly. Tubes were heated at $60^{\circ} \mathrm{C}$ for $15 \mathrm{~min}$, then $0.2 \mathrm{ml} \mathrm{NaOH}-\mathrm{H}_{2} \mathrm{O}_{2}{ }^{2}$ was added, mixed thoroughly and the tubes were heated $60^{\circ} \mathrm{C}$ for $10 \mathrm{~min}$. One $\mathrm{ml}$ of water was added to the tubes and the contents were mixed thoroughly and the fluorescence read immediately in an Aminco-Bowman spectrophotofluorometer (excitation at $360 \mathrm{mu}$ and emission at 460 mu, sensitivity setting at 50 and slit width of $1 / 64$ in). Values were reported as umoles GABA/g brain (wet weight). Measurement of Glutamic Acid Decarboxylase Activity:

The assay procedure was that of Roberts and Simonsen (1963). The C-14-L-glutamic acid substrate solution was made by combining $1 \mathrm{ml}$ of $1-\mathrm{C}-14-\mathrm{L}-\mathrm{glutamic}$ acid ( 25 micro Ci), $25 \mathrm{ml}$ of $0.2 \mathrm{M} \mathrm{L-glutamic} \mathrm{acid} \mathrm{adjusted} \mathrm{to} \mathrm{pH} 6.5$ with $\mathrm{KOH}, 10 \mathrm{ml}$ of 5 per cent $(\mathrm{v} / \mathrm{v})$ Triton $\mathrm{X}-100,36 \mathrm{ml}$ of $0.4 \mathrm{M}$

${ }^{1}$ Prepared by dissolving $15.2 \mathrm{~g} \mathrm{Na}_{3} \mathrm{PO}_{4}-12 \mathrm{H}_{2} \mathrm{O}$ and $2.68 \mathrm{~g}$ $\mathrm{Na}_{2} \mathrm{HPO}_{4}$ in sufficient water to make $100 \mathrm{ml}$. Solution was stored in amber bottle at room temperature.

${ }^{2}$ Prepared fresh just prior to use by adding $0.2 \mathrm{ml} 3 \%$ $\mathrm{H}_{2} \mathrm{O}_{2}$ to $10 \mathrm{ml}$ of $1 \mathrm{ON} \mathrm{NaOH}$. 
potassium phosphate buffer $(\mathrm{pH} 6.5)$ and $5 \mathrm{mg}$ pyridoxal phosphate. This solution was adjusted to a final volume of $100 \mathrm{ml}$ with $0.2 \mathrm{M}$ potassium phosphate buffer ${ }^{2}$ ( $\mathrm{pH}$ 6.5). The solution was $5 \times 10^{-2} \mathrm{M}$ in $1-\mathrm{C}-14$ glutamate (sp. act. 1.25 uc/umole), $2 \times 10^{-4} \mathrm{M}$ in pyridoxal phosphate, 0.5 per cent in Triton $\mathrm{X}-100$ and $0.2 \mathrm{M}$ in phosphate. The final $\mathrm{pH}$ was 6.5 and the mixture was stored in $25 \mathrm{ml}$ portions at $-40^{\circ} \mathrm{C}$ until use.

The procedure for collection of brain samples was as described in the GABA-T assay except that brains were homogenized in 7 vol of ice-cold deionized water. One ml of homogenate was added to a scintillation vial that was used as an incubation flask and one $\mathrm{ml}$ of Hyamine 10-X was added to another vial. The unit ${ }^{3}$ was assembled and the homogenates were preincubated at $37^{\circ} \mathrm{C}$ for 10 min during which time each flask was flushed with 100 per cent nitrogen for 2 min. The reaction was started by the addition of one ml of substrate

${ }^{1}$ Prepared by adding 0.4 dibasic potassium phosphate to 0.4 M monobasic potassium phosphate until pH 6.5 was reached.

${ }^{2}$ Prepared by adding $0.2 \mathrm{M}$ dibasic potassium phosphate to $0.2 \mathrm{M}$ monobasic potassium phosphate until a $\mathrm{pH}$ of 6.5 was reached.

3Te unit consisted of 2 counting vials connected by a glass $U$ tube ( $1 / 4$ in I.D.). The vials and U tube were connected by means of $1 / 2$ in lengths of high pressure tubing (soft rubber -- $1 / 4$ in I.D., 5/8 in O.D.). Two needles (23 gauge, 1 in) per unit vere inserted through the tubing and removed after addition of $\mathrm{C}-14$ substrate. Sulfuric acid was introduced through the tubing by means of a needle and syringe at the end of the incubation period. During preincubation and after nitrogen flush, needles were stoppered with $1 / 8$ in O.D. glass tubing sealed at both ends. 
solution (warmed to $37^{\circ} \mathrm{C}$ ) by means of a hypodermic syringe. The needles were immediately removed to seal the unit and the samples were incubated at $37^{\circ} \mathrm{C}$ in a Dubnoff metabolic shaker.

At the end of exactly 15 min, $0.2 \mathrm{cc}$ of $4 \mathrm{~N}$ sulfuric acid was added to stop the reaction. The units were allowed to shake for another $60 \mathrm{~min}$ to insure complete absorption of the $\mathrm{C}-14-\mathrm{O}_{2}$ by Hyamine (10-X). The counting vial was detached and $10 \mathrm{ml}$ of scintillation solution ${ }^{1}$ was added. Radioactivity was counted in a Packard Tri-Carb 1iquid scintillation spectrometer ( 25 per cent gain setting). Internal standards of C-14 toluene (New England Nuclear) were added to every other sample for determination of per cent efficiency. All samples were counted for 10 min. valües were reported as umoles $\mathrm{CO}_{2} / \mathrm{gm}$ brain/hr.

Measurement of Gamma-Aminobutyric Acid Transaminase Activity The GABA-T assay procedure was that of Salvador and Albers (1959). Brains were removed rapidly with the aid of other investigators, weighed and homogenized in three vol ice-cold 1.25 per cent Triton X-100. Five ml of GABAalpha- $\mathrm{KG}^{2}$ mixture was added to $0.2 \mathrm{ml}$ of homogenate. One-

${ }^{1}$ Prepared by dissolving 1 g POPOP (1,4-bis 2-(5-phenyloxazolyl) benzene) and $0.1 \mathrm{~g}$ PPO (s,5 diphenyloxazole) in sufficient toluene to make I liter.

2

Prepared by dissolving $2.575 \mathrm{G}$ GABA and $1.46 \mathrm{~g}$-KG ir. 50 ml water. The $\mathrm{pH}$ was brought to 8.4 with $5 \mathrm{~N}$ NaOH and the volume adjusted to $100 \mathrm{ml}$ with water. This mixture was prepared fresh daily and was 0.25M GABA and 0.1M in -KG. 
half ml samples of this mixture were added to $0.5 \mathrm{ml}$ of DAB reagent $^{1}$ (Salganicoff and DeRobertis, 1965) and stored on ice for use as tissue blanks. The removal of brains, weighing and homogenization procedures took no longer than 45 min. for 20 mice.

The succinic semialdehyde standard was prepared according to Prescott and Waelsch (1346). Twenty mg ninhydrin was mixed with $1.4 \mathrm{ml}$ glutamic acid solution $(0.001 \mathrm{~g} / \mathrm{ml}$ in $0.5 \mathrm{~N}$ acetic acid) after which time $2.6 \mathrm{ml}$ of $0.5 \mathrm{~N}$ acetic acid was added. Reagent blanks contained $4 \mathrm{mI}$ of $0.5 \mathrm{~N}$ acetic acid and $20 \mathrm{mg}$ ninhydrin, Reagent blanks and standards were placed in boiling water for 10 min. After the tubes were cooled in ice, the following reagents were added at 5 min intervals: $0.4 \mathrm{ml}$ guanidine carbonate ( 14 per cent in water), $1 \mathrm{ml}$ lead acetate ( 12 per cent in water prepared fresh each day), $0.5 \mathrm{ml}$ of $5 \mathrm{~N} \mathrm{NaOH}$ and $0.1 \mathrm{ml}$ water. Tutes were centrifuged at 3,000 rpm for $10 \mathrm{~min}$ in a clinical centrifuge. After centrifugation, $0.5 \mathrm{ml}$ aliquots of zeagent blank and stardard were added to $0.5 \mathrm{ml}$ of DAB reagent, mixed and stored on ice.

The GABA- $C-$ KG mixture containing brain homogenate was incubated in a Dubnoff metabolic shaker under room air at $37^{\circ} \mathrm{C}$ for $60 \mathrm{~min}$. After incubation, $0.5 \mathrm{ml}$ aliquots were added to $0.5 \mathrm{~m} 1 \mathrm{DAB}$ reagent.

${ }^{1}$ Prepared by dissolving 2.8 g 3.5 diaminobensoic acid HCI in $25 \mathrm{ml} 1 \mathrm{M}$ potassium phosphate buffer ( $\mathrm{pH} 5.9$ ) ( 1 vol of $1 \mathrm{M} \mathrm{K} \mathrm{K}_{2} \mathrm{HOP}_{4}$ plus 9 vol of $1 \mathrm{M} \mathrm{KH} \mathrm{KH}_{2}$ ). The pH was brought to 5.9 with $^{4} 5 \mathrm{~N} \mathrm{NaOH}$ and adjusted to a final volume of 50 rl with phosphate buffer. 
Samples, tissue blanks, reagent blanks and standards were heated at $60^{\circ} \mathrm{C}$ for 60 min. Nine ml water was added to each tube and tubes were centrifuged at 3,000 rpm for 10 min. Forty ul of supernatant was mixed with $10 \mathrm{ml}$ water and samples were read in an Aminco-Bowman spectrophotofluorometer (excitation $405 \mathrm{mu}$, emission $505 \mathrm{mu}$, sensitivity setting at 50 and slit width of $1 / 64 \mathrm{in}$ ). Values were reported as umoles succinic semialdehyde/gm brain/hr.

\section{Determination of Brain Protein}

The assay method was that of Lowry et al. (1951). Brains were removed rapidly, weighed and homogenized in 9 vol of isotonic $(1.15 \%) \mathrm{KCl}$. A $0.4 \mathrm{ml}$ aliquot of the supernate, obtalned after centrifugation of the whole homogenate at $10,000 \mathrm{rpm}$ for $20 \mathrm{~min}$, was added to $1.6 \mathrm{ml}$ of $0.5 \mathrm{~N} \mathrm{NaOH}$. The test tubes were then placed in a boiling water bath to hasten dissolution. Following one hour in the water bath, a $0.2 \mathrm{~m} 1$ of the diluted sample was added to $1 \mathrm{ml}$ of $0.5 \mathrm{~N}$ $\mathrm{NaOH}$. To this was added $5 \mathrm{ml}$ of reagent $\mathrm{A}^{1}$ and mixed for 10 seconds. Twenty minutes subsequent to the last addition, $0.5 \mathrm{ml}$ of a commercial Folin-Phenol reagent (diluted to $1 \mathrm{~N}$ with distilled water) was mixed with the sample. The sample was allowed to stand at a room temperature for 40 minutes. The intensity of the blue color was read at $500 \mathrm{mu}$. A blank prepared using $1.15 \% \mathrm{KCl}$ and was treated as the other samples. Bovine serum albumin was used as a standard.

${ }^{1}$ Reagent A: $1.0 \mathrm{ml}$ of $1 \%$ aqueous $\mathrm{CuSO}_{4}, 1.0 \mathrm{ml}$ of $2.7 \%$ aqueous potassium tartrate added to $100 \mathrm{ml}$ of $2 \%$ aqueous $\mathrm{Na}_{2} \mathrm{CO}_{3}$ 
Statistical Methods:

The student " $t$ " test for independent means, Chisquare 2 x 2 contingency analysis (Dixon and Massey, 1969) were used to test for differences between control and experimental groups. Correlation coefficients were calculated using linear regression analysis (Dixon and Massey, 1969). The results were also analyzed by the analysis of variance using a mixed-effects model (Dixon and Massey, 1969).

Tests were perforned on an Olivetti Underwood Programma 101 desk computer and IBM computer 360/50. The exact level of significance was determined from the respective standard tables. 
RESULTS

In order to determine the relationship between alteration in CNS sensitivity to barbiturates and changes in brain GABA levels we altered the GNS sensitivity of the animals to barbiturates by utilizing the following known conditions:

A) exposure to hypobaric hypoxia

B) septal lesions

c) treaiment with drugs, desipramine (DMI), sodium nitrite or pargyline

D) social deprivation

E) abrupt withdrawal following chronic barbiturate or alcohol administration.

The brain $\mathrm{BABA}-1$ evels were determined after the above treatments. 


\section{A. ACUTE HYPOXIA}

Since acute hypobaric hypoxia, $364 \mathrm{~mm} \mathrm{Hg}\left(\mathrm{pO}_{2}=76 \mathrm{~mm} \mathrm{Hg}\right)$ has been reported to alter the brain sensitivity of mice to barbiturates (Baumel et al., 1970b), we used the similar hypoxic exposure in our study. Further, the magnitude of alteration in brain sensitivity differed at $22^{\circ} \mathrm{C}$ and at $30^{\circ} \mathrm{C}$ ambient temperature (Baume1, 1970). Therefore, we measured brain gamma-aminobutyric acid at both $22^{\circ} \mathrm{C}$ and $30^{\circ} \mathrm{C}$ ambient temperature.

\section{Effect of Hypoxia on Brain Gamma-aminobutyric Acid}

Table 1 summarizes the effect of acute exposure to hypobaric hypoxia (364 $\mathrm{mm} \mathrm{Hg}, \mathrm{po}_{2}=76 \mathrm{~mm} \mathrm{Hg}$ ) on mouse brain GABA-1eve1s. The brain GABA-levels were markedly elevated . under the hypobaric environment, during both 30 and 60 minute exposures. However, the magnitude of increase in brain GABA differed at $22^{\circ} \mathrm{C}$ and $30^{\circ} \mathrm{C}$ ambient temperature. The hypoxic exposure for 30 or 60 minutes at $22^{\circ} \mathrm{C}$ ambient temperature caused 49 and $54 \%$ increase in brain GABA-levels, while hypoxic exposure at $30^{\circ} \mathrm{C}$ ambient temperature produced only 29 and $40 \%$ increase in brain GABA concentrations, respectively.

The analysis of variance summarized in Table 1 shows the effect of three factors, namely, hypoxia, hypoxia duration, and ambient temperature, and their interactions on brain GABA-1evels. It can be seen that only hypoxia had a significant effect on brain GABA, while hypoxia duration and ambient temperature had no significant interaction with 
TABLE 1

EFFECT OF HYPOBARIC HYPOXIA ON MOUSE BRAIN LEVELS OF GAMMAAMINOBUTYRIC ACID AT TWO AMBIENT TEMPERATURES

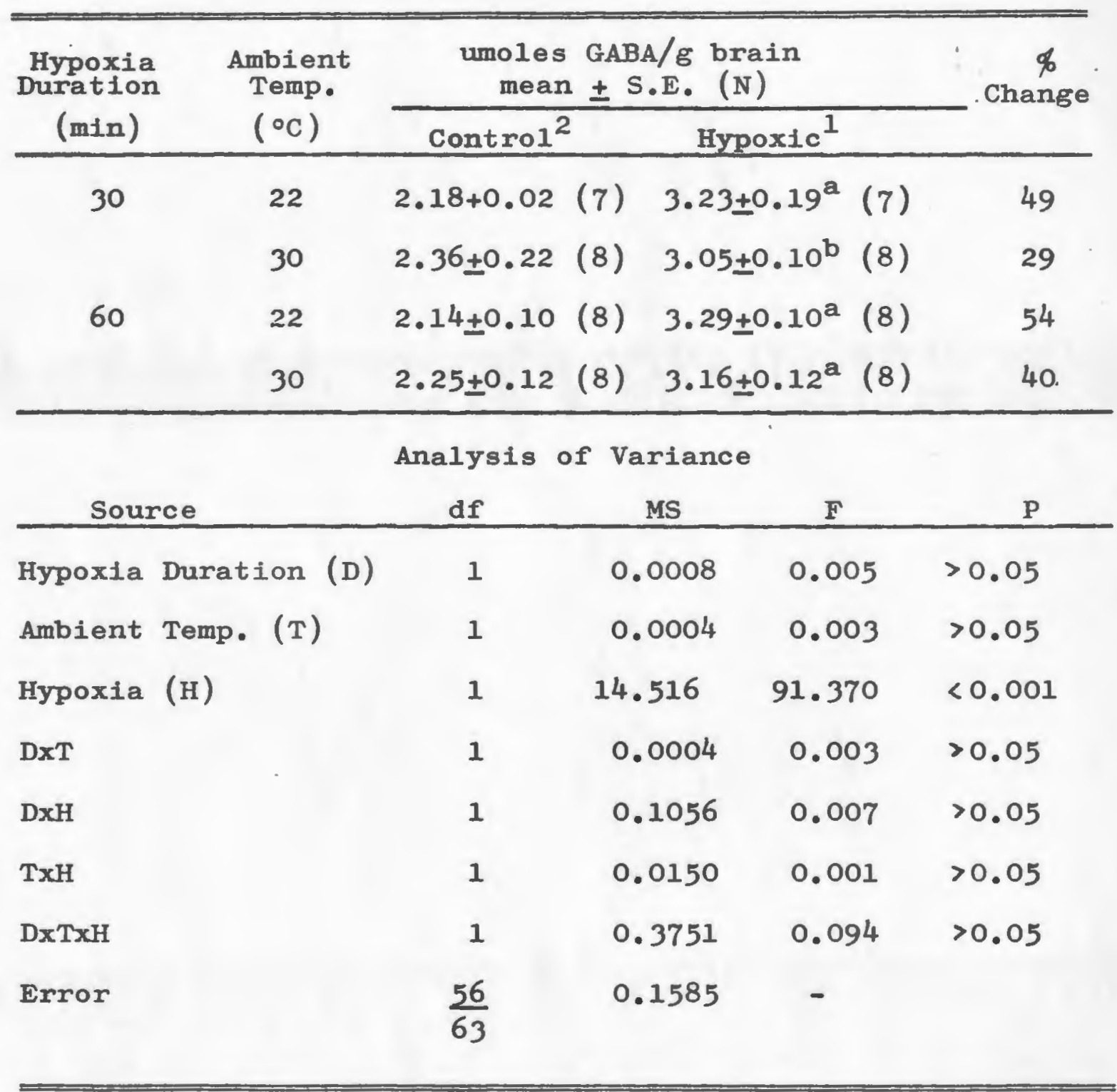

1. $364 \mathrm{~mm} \mathrm{Hg}, \mathrm{pO}_{2}=76 \mathrm{~mm} \mathrm{Hg}$ (equivalent to a $10 \%$ oxygen atmosphere $a t^{2}$ sea level).

2. Controls were run concurrently in identical chambers open to room air.

Control vs. hypobaric;

${ }_{\mathrm{p}<0.001}$

$b_{p<0.01}$ 
the effect of hypoxia on brain GABA.

\section{B. SEPTAL LESIONS}

Heller et al. (1960) found that lesions in the septal area in rats caused a 3-fold increase in barbital-induced narcosis, as compared with normal controls. This effect was found to be specific to the septal region (see Harvey et al.., 1964). Considering this, we measured barbital induced narcosis in septal rats at first, to make sure that the lesions were in the septal area, and then determined the brain levels of GABA.

1. Effect of Septal Lesions on Barbital Induced-Narcosis and Brain Gamma-aminobutyric Acid

The testing of septal rats with barbital was done on the 25 th postoperative day. The results are summarized in Table 2. Bilateral lesions of the septal area produced marked increase in barbital induced-narcosis and decrease in onset of narcosis. The brain levels of GABA in the same septal rats were determined on the 35 th postoperative day. Duty summarized in Table 2 show that there nas no significant difference in the levels of brain GABA between the septal rats and sham-operated or normal control rats.

\section{DRUG TREATMENTS}

One hour pretreatment with DMI (Shah and La1, 1971) or half hour pretreatment with sodium nitrite (Baumel et al., 1971) have been reported to alter the neuronal sensitivity 
TABLE 2

EFFECT OF SEPTAL LESIONS ON BARBITAL NARCOSIS AND BRAIN LEVELS

OF GAMMA-AMINOBUTYRIC ACID IN RATS

\begin{tabular}{|c|c|c|c|}
\hline \multirow[t]{2}{*}{$\begin{array}{c}\text { Experimental } \\
\text { Groups }\end{array}$} & \multicolumn{2}{|c|}{$\begin{array}{l}\text { Barbital }{ }^{1} \text { Narcosis } \\
\text { Min. } \pm S . E .(N)\end{array}$} & \multirow[t]{2}{*}{$\begin{array}{c}\text { umoles } \mathrm{GABA}^{4} / \mathrm{g} \text { brain } \\
\text { Mean } \pm \mathrm{S} \cdot \mathrm{E} \cdot(\mathrm{N})\end{array}$} \\
\hline & Onset & Duration & \\
\hline Normal Controls & $76.0 \pm 8.1$ & $98.1 \pm 12.3 \quad$ (6) & $2.33 \pm 0.08 \quad(8)$ \\
\hline Sham Operated 2 & $77.8 \pm 10.6^{a}(6)$ & $131.8 \pm 19.7^{a}(6)$ & $2.40 \pm 0.08^{a}$ (8) \\
\hline Septal ${ }^{3}$ & $31.5 \pm 7.1^{b}(6)$ & $321.6 \pm 36.7^{b} \quad(6)$ & $2.53 \pm 0.10^{c} \quad(7)$ \\
\hline
\end{tabular}

1. $160 \mathrm{mg} / \mathrm{kg}$ injected intraperitoneal1y.

2. Rats with drilled skulls, but intact dura.

3. Rats with bilateral stereotoxically placed electrolytic lesions in the septal area of the basal telencephalon.

4. Rat heads were frozen in 1iquid nitrogen prior to the measurement of GABA in the brain.

Normal controls vs. Sham-operated.

$a_{p}<0.05$

Normal controls or sham-operated vs. Septal.

$\mathrm{b}_{p}<0.001$

$c_{p}>0.05$ 
to barbiturates, at $22^{\circ} \mathrm{C}$ but not at $30^{\circ} \mathrm{C}$ ambient temperature. Pargyline, unlike DMI or sodium nitrite, altered the CNS sensitivity of our animals to barbital at both $22^{\circ} \mathrm{C}$ and at $30^{\circ} \mathrm{C}$ ambient temperature (Table 6). Therefore, we measured brain levels of GABA in mice after DMI, sodium nitrite or pargyline (100 mg/kg, two hours) pretreatment at both $22^{\circ} \mathrm{C}$ and at $30^{\circ} \mathrm{C}$ ambient temperature, utilizing the same dosage and the same pretreatment time as reported by the aforementioned workers.

1. Effect of Desipramine (DMI) on Brain Gamma-aminobutyric Acld and Body Temperature at Two Ambient Temperatures

Table 3 shows the effect of DMI, $50 \mathrm{mg} / \mathrm{kg}, 1 . \mathrm{p} .$, on brain GABA-levels at two ambient temperatures, $22^{\circ} \mathrm{C}$ and $30^{\circ} \mathrm{C}$. DMI pretreatment caused a significant elevation in brain GABA at $22^{\circ} \mathrm{C}$ ambient temperature. However, the increase in brain levels of GABA caused by DMI at $22^{\circ} \mathrm{C}$ was absent at the higher ambient temperature.

The analysis of varlance summarized in Table 3 shows the effect of two factors, namely, ambient temperature and DMI, and their interaction on brain GABA-1evels. It can be seen that both ambient temperature and DMI had a significant effect on brain GABA. Also, there was a significant interaction between ambient temperature and DMI for their effect on brain levels of GABA. These data suggest that $30^{\circ} \mathrm{C}$ prevented the increase in brain GABA caused by DMI at $22^{\circ} \mathrm{C}$ ambient temperature. Furthermore, $30^{\circ} \mathrm{C}$ by itself caused re- 
TABLE 3

EFFECT OF DESIPRAMINE ON BODY TEMPERATURE AND

BRAIN LEVELS OF GAMMA-AMINOBUTYRIC ACID

AT TWO AMBIENT TEMPERATURES IN MICE

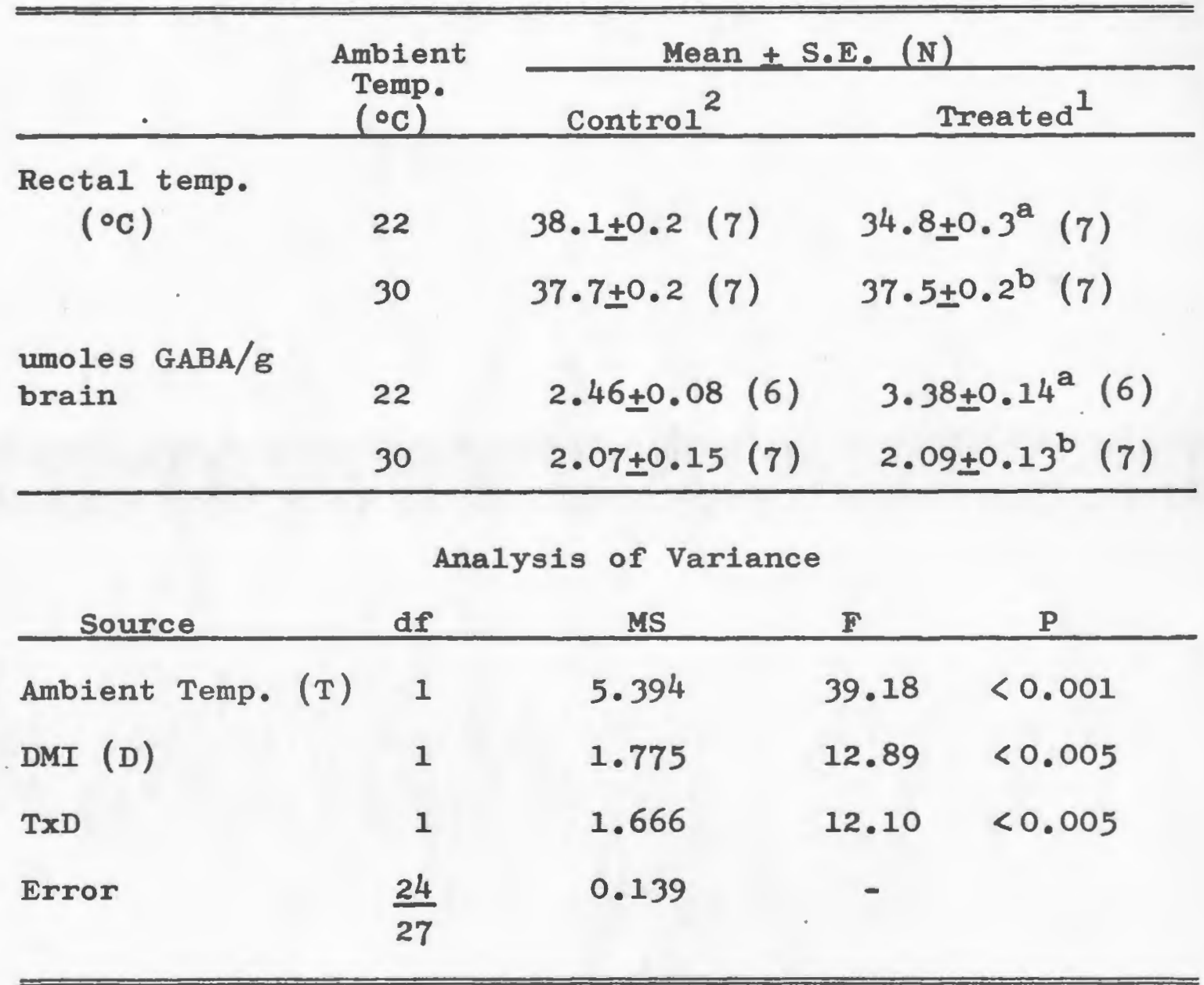

1. Desipramine $(50 \mathrm{mg} / \mathrm{kg})$ injected intraperitoneally 1 hour prior to freezing in liquid nitrogen.

2. Distilled water $(10 \mathrm{ml} / \mathrm{kg})$ injected intraperitoneally 1 hour prior to freezing.

Control vs. Treated

$$
\begin{aligned}
& a_{p}<0.005 \\
& b_{p}<0.05
\end{aligned}
$$


TABLE 4

EFFECT OF VARIOUS DOSES OF DESIPRAMINE ON MOUSE BRAIN LEVELS OF GAMMA-AMINOBUTYRIC ACID AT $22^{\circ} \mathrm{C}$ AMBIENT TEMPERATURE

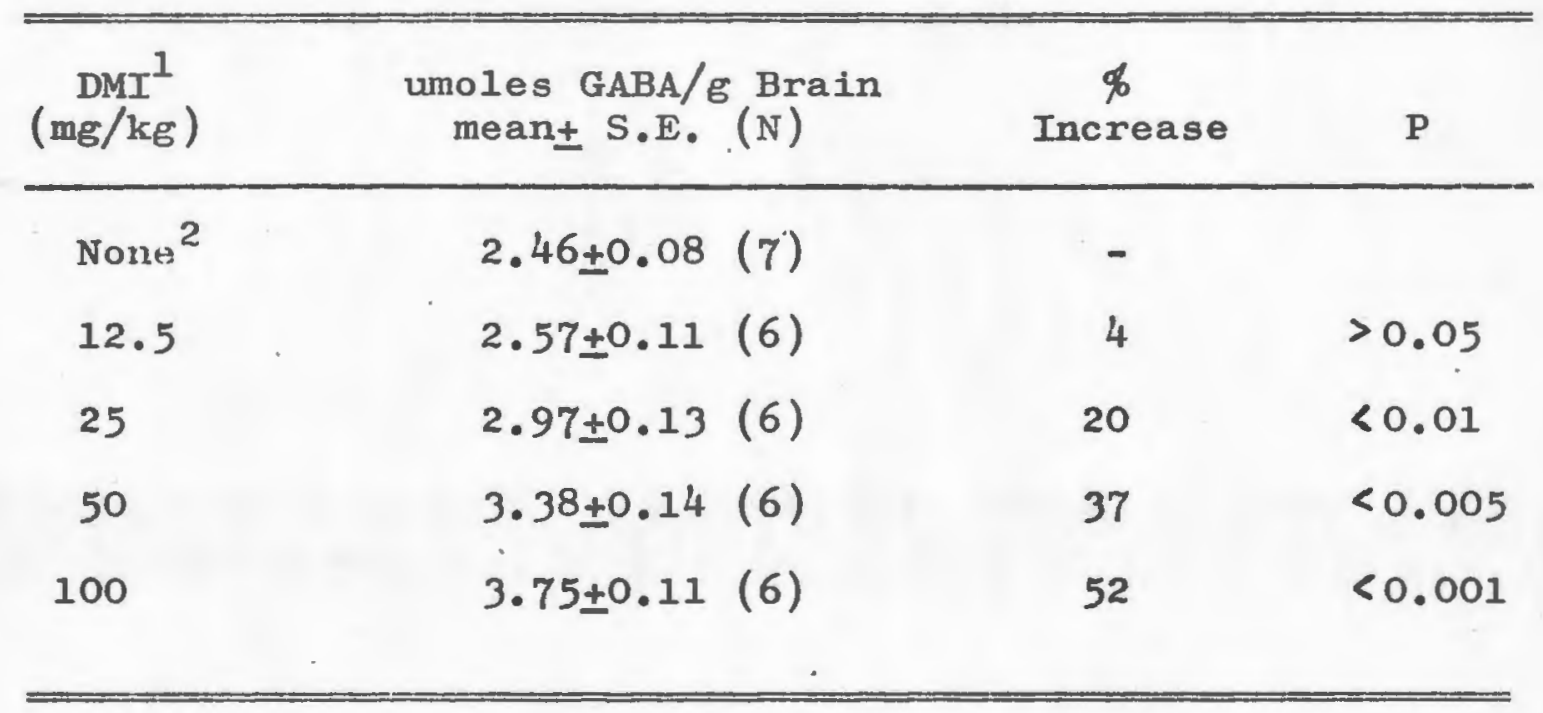

1. Desipramine infected intraperitoneally 1 hour prior to freezing in liquid nitrogen.

2. Distilled water $(10 \mathrm{ml} / \mathrm{kg})$ injected intraperitoneally 1 hour prior to freezing. 


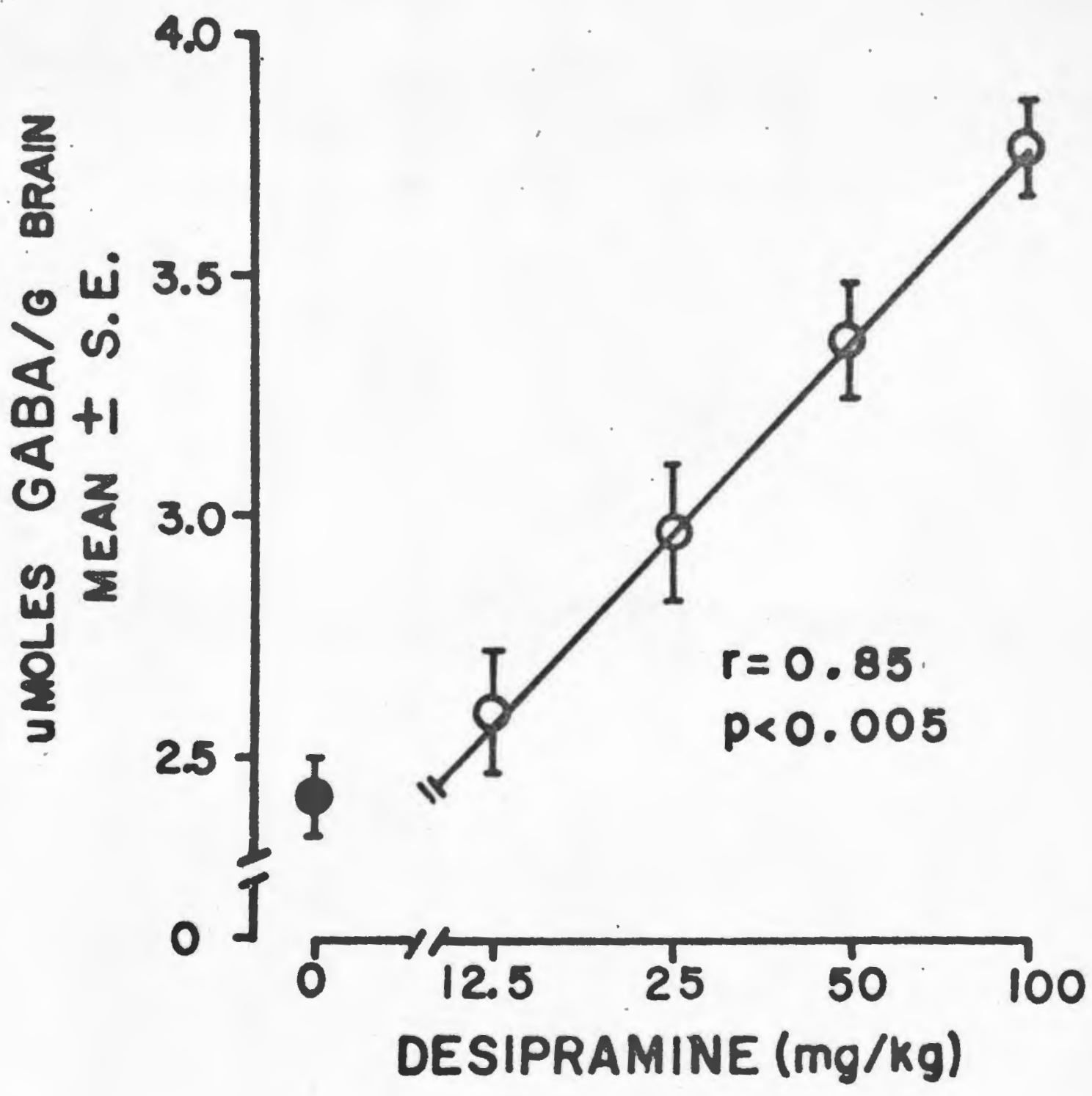

Figure 7. EFFECT OF VARIOUS DOSES OF DESIPRAMINE ON MOUSE BRAIN LEVELS OF GAMMA-AMINOBUTYRIC ACID AT $22^{\circ} \mathrm{C}$ AMBIENT TEMPERATURE. Desipramine was administered 60 minutes prior to sacrifice. Each point represents the mean \pm S.E. Seven animals were used for the control and six for each dose level. Open symbols denote significant $(p<0.01)$ difference from controls. P value represents rejection of the hypothesis that the correlation coefficient $(r)$ equals zero. 
duction of brain GABA-levels in control animals as compared to the control animals exposed at $22^{\circ} \mathrm{C}$ ambient temperature. Since DMI pretreatment, at $22^{\circ} \mathrm{C}$ but not at $30^{\circ} \mathrm{C}$ ambient temperature, caused a dose-dependent hypothermia (Shah and Lal, 1971) with an optimum at one hour, this time period was used to investigate the effect of various doses of DMI on brain GABA-levels. Actual means, standard errors, levels of significance and percent increase in brain GABA are shown in Table 4. Figure 7 illustrates the dose-dependent effect of DMI on brain GABA-levels. There was a significant correlation $(x=0.85, p<0.005)$ between the dose of DMI and elevation of brain GABA.

The effect of DMI on rectal temperature of mice at two ambient temperatures, $22^{\circ}$ and $30^{\circ} \mathrm{C}$, is described in Table 4. At $22^{\circ} \mathrm{C}$ ambient temperature, DMI caused a significant reduction in body temperature with an optimum at one hour. However, hypothermia caused by DMI at $22^{\circ} \mathrm{C}$ was absent at the higher ambient temperature. Similarly, elevation in brain GABA caused by DMI at $22^{\circ} \mathrm{C}$ was absent at $30^{\circ} \mathrm{C}$ ambient temperature.

2. Effect of Sodium Nitrite on Brain Gamma-aminobutrric Acid and Body Temperature at Two Ambient Temperatures

Table 5 shows the effect of sodiun nitrite, $100 \mathrm{mg} /$ kg, i.p., on brain GABA-levels at two ambient temperacures, $22^{\circ}$ and $30^{\circ} \mathrm{C}$. At $22^{\circ} \mathrm{C}$ ambient temperature, sodium nitrite caused a significant elevation in brain GABA. However, the 


\section{TABLE 5}

EFFECT OF SODIUN NITRITE ON BODY TEMPERATURE AND

BRAIN LEVELS OF GAMMA-AMINOBUTYRIC ACID AT

TWO AMBIENT TEMPERATURES IN MTCE

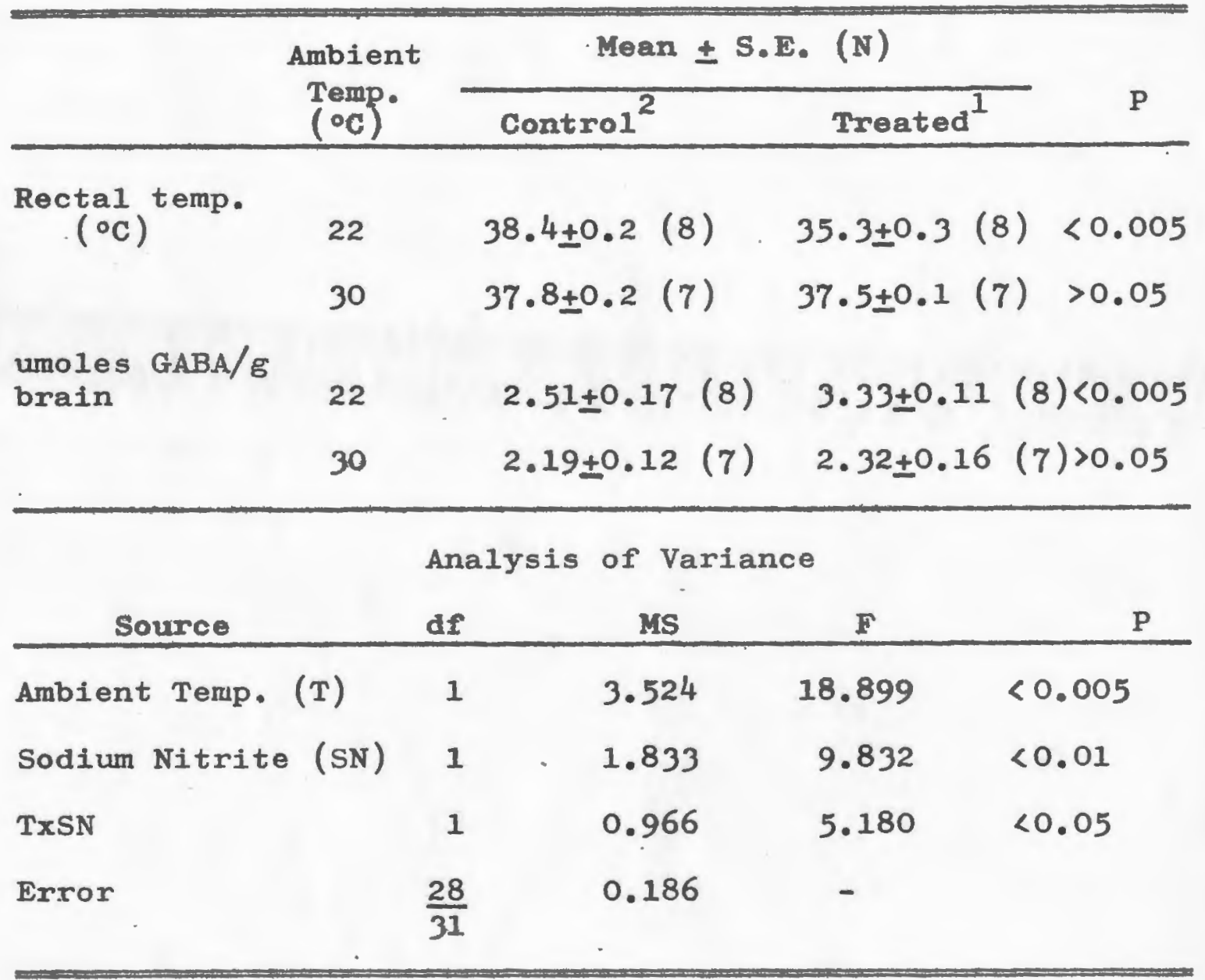

1. Sodium nitrite $(100 \mathrm{mg} / \mathrm{kg})$ injected intraperttoneally 30 minutes prior to freezing in liquid nitrogen.

2. Distilled water $(10 \mathrm{ml} / \mathrm{kg}$ ) injected intraperitoneally 30 minutes prior to freezing. 
increase in brain GABA caused by sodium nitrite at $22^{\circ} \mathrm{C}$ was absent at the higher ambient temperature.

Data summarized in Table 5 also describes the effect of sodium nitrite on rectal temperature of mice at two ambient temperatures, $22^{\circ} \mathrm{C}$ and $30^{\circ} \mathrm{C}$. It can be seen that sodium nitrite produced a significant reduction in body temperature at $22^{\circ} \mathrm{C}$ ambient temperature. The peak effect on body temperature occurred approximately 30 minutes after nitrite infection. However, hypothermia due to sodium nitrite at $22^{\circ} \mathrm{C}$ was prevented at $30^{\circ} \mathrm{C}$ ambient temperature. Similarly, elevation in brain GABA-levels caused by sodium nitrite at $22^{\circ} \mathrm{C}$ was absent at the higher ambient temperature.

The analysis of variance summarized in Table 5 show the effect of two factors, namely, ambient temperature and sodium nitrite, and their interactions on brain GABAlevels. It can be seen that both ambient temperature and sodium nitrite had a significant effect on brain levels of GABA. Also, there was a significant interaction between ambient temperature and sodium nitrite for their effect on brain GABA-1evels. These data indicate that $30^{\circ} \mathrm{C}$ prevented the increase in GABA caused by sodium nitrite at the lower ambient temperature. Furthermore $30^{\circ} \mathrm{C}$ by itself caused reduction of brain GABA-1evels in control animals as compared to the control animals exposed at $22^{\circ} \mathrm{C}$ ambient temperature. 
3. Effect of Pargyline on Barbital Induced-Narcosis, Body

Temperature and Brain Gamma-Aminobutyric Acid at Two Ambient

\section{Temperatures}

At both $22^{\circ} \mathrm{C}$ and $30^{\circ} \mathrm{C}$ ambient temperature, pargyline (100 mg/kg, i.p., $2 \mathrm{hr}$ pretreatment) potentiated narcosis induced by biologically stable barbiturate (barbital), produced hypothermia and elevated brain levels of GABA (Table 6). These effects were statistically significant in all cases. However, the magnitude of the effects produced by pargyline differed at both the ambient temperatures. At $22^{\circ} \mathrm{C}$, pargyline produced nearly 2-fold greater potentiation of narcosis due to barbital and a 2-fold greater decrease in rectal temperature of mice as compared to $30^{\circ} \mathrm{C}$ ambient temperature. The elevation in brain levels of GABA was also greater at $22^{\circ} \mathrm{C}$ as compared to the higher ambient temperature (Table 6).

Pretreatment of mice with various doses of pargyline at $22^{\circ} \mathrm{C}$ ambient temperature caused a marked reduction in body temperature, reaching a maximum drop of $3-6^{\circ}$ with $100 \mathrm{mg} / \mathrm{kg}$ and $6.1^{\circ}$ with $200 \mathrm{mg} / \mathrm{kg}$ dose (Figure 8). At $30^{\circ} \mathrm{C}$ ambient temperature, the drop in body temperature due to pargyline was only one half of what was seen during pargyline treatment at $22^{\circ} \mathrm{C}$, and reached a maximum drop of 1.80 with $100 \mathrm{mg} / \mathrm{kg}$ and 3.80 with $200 \mathrm{mg} / \mathrm{kg}$ dose (Figure 8). The analysis of variance summarized in Table 6 shows the effect of two factors, namely, ambient temperature and pargyline, and their interaction on brain levels of GABA. 


\section{TAPHF 6}

EFFECT OF PARGYLINE ON BARBITAL NARCOSIS, BODY TEMPERATURE AND BRAIN LEVELS

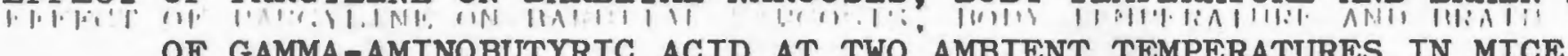

,

\begin{tabular}{|c|c|c|c|c|c|}
\hline & \multirow{2}{*}{$\begin{array}{l}\text { Ambient } \\
\text { Temp. } \\
\text { (oc) }\end{array}$} & \multicolumn{3}{|c|}{ Mean \pm S.E. (N) } & \multirow{2}{*}{$\begin{array}{c}\% \\
\text { Change }\end{array}$} \\
\hline & & Contro $1^{2}$ & Treated $^{1}$ & & \\
\hline \multirow{2}{*}{$\begin{array}{l}\text { Barbital } \\
\text { Narcosis } \\
\text { (min) }\end{array}$} & 22 & $129 \pm 13.1 \quad(7)$ & $261 \pm 15.0^{a}$ & (8) & 102 \\
\hline & 30 & $102 \pm 11.7 \quad$ (8) & $161 \pm 8.7^{a}$ & (8) & 58 \\
\hline \multirow[t]{2}{*}{$\begin{array}{c}\text { Rectal } \\
\left({ }^{\circ} \mathrm{C}\right)\end{array}$} & remp. & $38.7 \pm 0.1 \quad(6)$ & $34.8 \pm 0.5^{b}$ & (6) & 10 \\
\hline & 30 & $38.4 \pm 0.1 \quad(6)$ & $36.7 \pm 0.1^{b}$ & (6) & 4 \\
\hline \multirow[t]{2}{*}{$\begin{array}{l}\text { umoles G. } \\
\text { Brain }\end{array}$} & $\mathrm{GABA}^{4} / \mathrm{g}_{22}$ & $2.25 \pm 0.09(7)$ & $2.88 \pm 0.10^{b}$ & (7) & 28 \\
\hline & 30 & $2.29 \pm 0.11(7)$ & $2.79 \pm 0.14^{c}$ & (7) & 21 \\
\hline
\end{tabular}




\section{Table 6 (Continued)}

Analysis of Variance of Data on the Effect of Ambient Temperature and Pargyline on Brain Levels of Gamma-Aminobutyric Acid

\begin{tabular}{lcccc}
\hline \multicolumn{1}{c}{ Source } & df & MS & F & P \\
\hline Ambient Temp. (T) & 1 & 0.006 & 0.068 & $>0.05$ \\
Pargyline (P) & 1 & 2.228 & 22.152 & $<0.001$ \\
TxP & 1 & 0.030 & 0.300 & $>0.05$ \\
Error & $\frac{24}{27}$ & 0.100 & - & - \\
\hline
\end{tabular}

1. Pargyline $(100 \mathrm{mg} / \mathrm{kg})$ injected intraperitoneally 2 hours prior to 3 or 4 .

2. Distilled water $(10 \mathrm{ml} / \mathrm{kg})$ injected intraperitoneally 2 hours prior to 3 or 4 .

3. Barbital ( $300 \mathrm{mg} / \mathrm{kg}$ ) injected intraperitoneally.

4. Mice were frozen in liquid nitrogen before the determination of brain GABA.

Control vs. Treated: $\quad a_{p}<0.001 \quad b_{p}<0.005 \quad c_{p}<0.02$ 
TABLE 7

EFFECT OF VARIOUS DOSES OF PARGYLINE ON MOUSE BRAIN LEVELS OF GAMMA-AMINOBUTYRIC ACID AT $22^{\circ} \mathrm{C}$ AMBIENT TEMPERATURE

\begin{tabular}{cccc}
\hline $\begin{array}{c}\text { Pargyine } \\
(\mathrm{mg} / \mathrm{kg})\end{array}$ & $\begin{array}{c}\text { umoles GABA/g brain } \\
\text { mean } \pm \mathrm{S.E} .(\mathrm{N})\end{array}$ & $\begin{array}{c}\% \\
\text { increase }\end{array}$ & $P$ \\
\hline None $^{2}$ & $2.20 \pm 0.05(6)$ & - & \\
25 & $2.32 \pm 0.12(5)$ & 5 & $>0.05$ \\
50 & $2.64 \pm 0.09(5)$ & 20 & $<0.005$ \\
100 & $2.90 \pm 0.12(6)$ & 31 & $<0.001$ \\
200 & $3.08 \pm 0.13(5)$ & 39 & $<0.001$ \\
\hline
\end{tabular}

1. Pärgyline injected intraperitoneally 2 hours prior to freezing in liquid nitrogen.

2. Distilled water $(10 \mathrm{ml} / \mathrm{kg})$ injected intraperitoneally 2-hours -prior to freezing. 


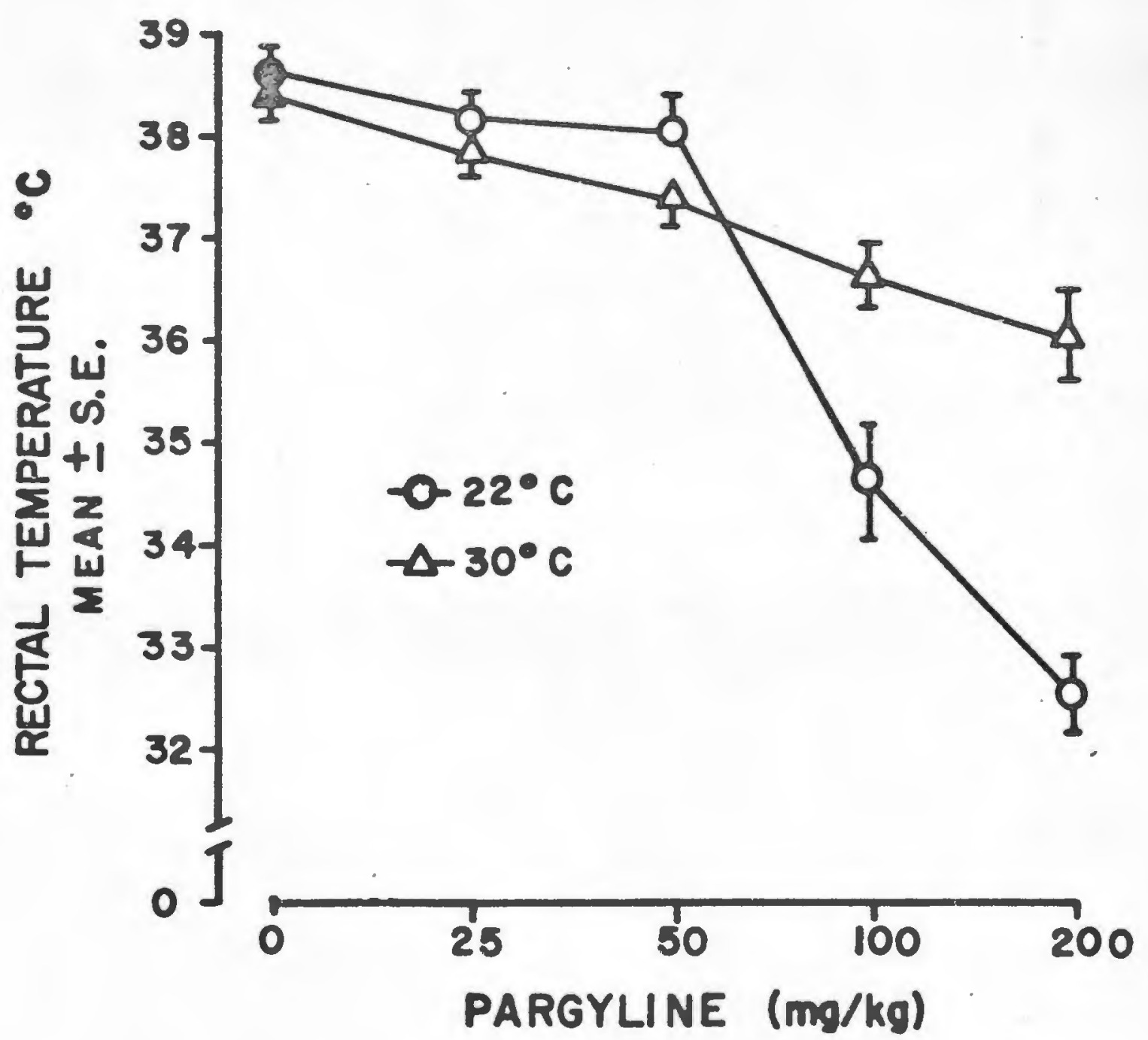

Figure 8. EFFECT OF PARGYLINE (mg/kg intraperitoneally) ON RECTAL TEMPERATURE OF MICE AT TWO AMBIENT TEMPERATURES. Pargyline was administered 120 minutes prior to the measurement of rectal temperature. Each point represents mean t S.E. of 6 animals. Open symbols denote significant difference $(p<0.01)$ from saline controls. 


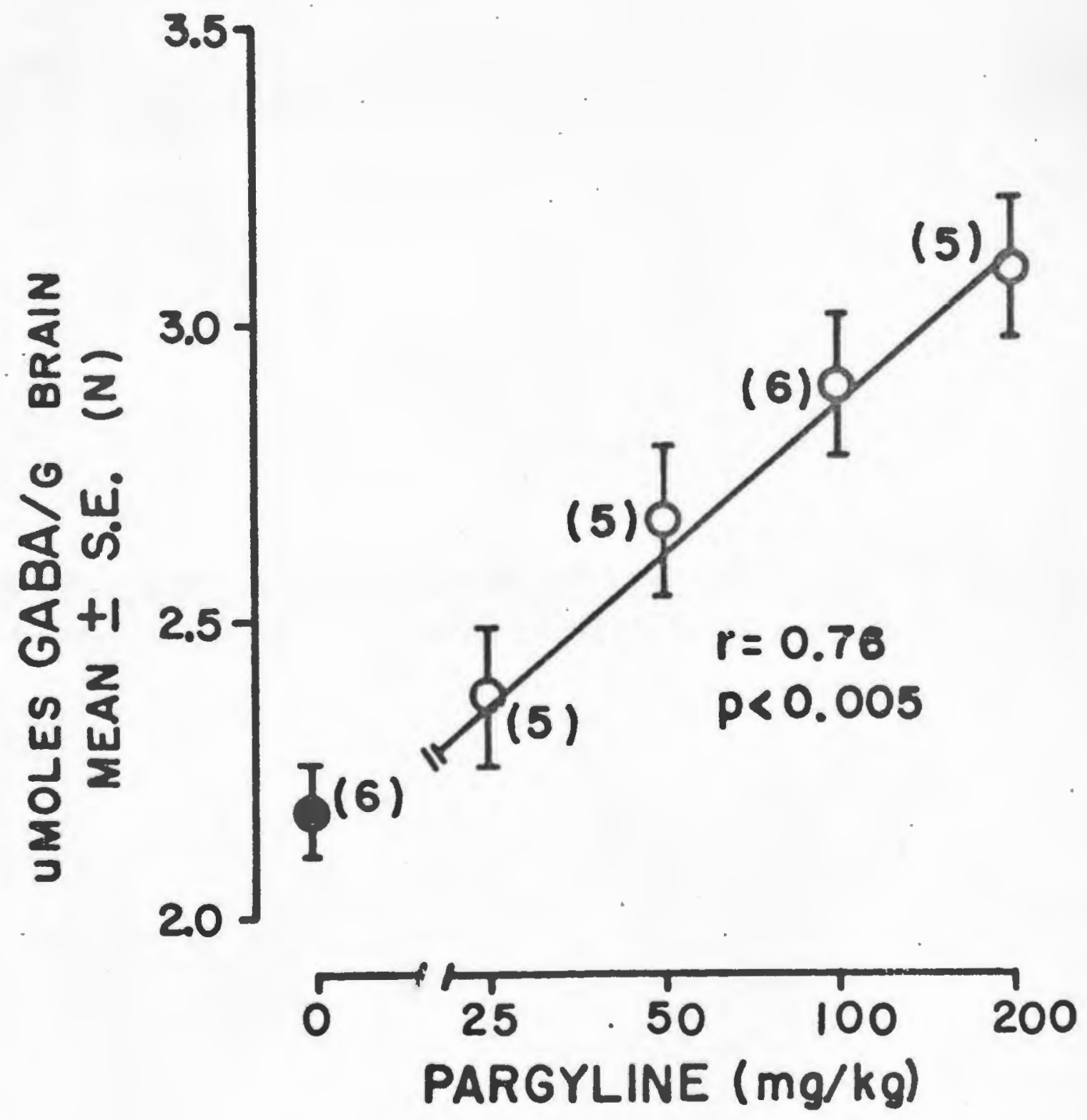

Figure 9. EFFECT OF VARIOUS DOSES OF PARGYLINE ON MOUSE BRAIN LEVELS OF GAMMA-AMINOBUTYRIC ACID AT $22^{\circ} \mathrm{C}$ AMBIENT TEMPERATURE. PargYline was administered 120 minutes prior to sacrifice. Each point represents the mean \pm S.E. Numbers in parentheses represents number of animals used. Open symbols denote significant $(p<0.05)$ difference from controls. P value represents rejection of the hypothesis that the correlation coefficient ( $r$ ) equals zero. 
Pargyline had a significant effect on brain GABA, while ambient temperature on pargyline and ambient temperature failed to affect brain levels of GABA. These data indicate that $30^{\circ} \mathrm{C}$ did not prevent the increase in GABA caused by pargyline at the lower ambient temperature. Further, the higher ambient temperature by itself failed to affect brain GABAlevels of control animals.

Since an optimum drop in body temperature was observed 120 minutes after pargyline injection, this time period was used to investigate the effect of various doses of pargyline on brain GABA-levels. Actual means, standard errors, levels of significance and percent increase in brain GABA are shown in Table 7. Figure 9 illustrates the dose-dependent effect of pargyline on brain GABA-levels. There was a significant correlation $(r=0.76, p<0.005)$ between the dose of pargyline and elevation of brain GABA.

\section{SOCIAL DEPRIVATION}

Since prolonged social deprivation has been reported to lower the neuronal sensitivity of mice to barbiturates (Baume1, et al., 1970a), we measured brain levels of GABA following different intervals of social deprivation.

\section{Effect of Social Deprivation on Brain Gamma-amino-} butyric acid

Data summarized in Table 8 shows the effect of social deprivation on mouse brain GABA-levels. Social deprivation for one day or seven days did not affect brain 
TABLE 8

EFFECT OF SOCIAL DEPRIVATION OR SOCIAL INTERACTION ON MOUSE BRAIN LEVELS OF GAMMA-AMTHOBUTYRIC ACID

\begin{tabular}{|c|c|c|c|c|}
\hline \multirow{2}{*}{$\begin{array}{c}\text { Days - } \\
\text { of } \\
\text { Social } \\
\text { Environment } \\
\end{array}$} & \multicolumn{2}{|c|}{$\begin{array}{c}\text { umoles GABA/g brain } \\
\text { mean } \pm \mathrm{S} . \mathrm{E} .(\mathrm{N})\end{array}$} & \multirow[b]{2}{*}{$\begin{array}{c}\% \\
\text { Change } \\
\end{array}$} & \multirow[b]{2}{*}{$\mathbf{P}$} \\
\hline & $\begin{array}{c}\text { Social } 2 \\
\text { Interaction }\end{array}$ & $\begin{array}{c}\text { Social } \frac{1}{6} \\
\text { Deprivation }\end{array}$ & & \\
\hline 1. & $2.44 \pm 0.13(7)$ & $2.43 \pm 0.06(7)$ & 0.4 & $>0.05$ \\
\hline $7^{-}$ & $2.30 \pm 0.08$ (8) & $2.24 \pm 0.15(8)$ & 3 & $>0.05$ \\
\hline 14. & $2.65 \pm 0.12 \quad(8)$ & $2.01 \pm 0.09(8)$ & 23 & $<0.005$ \\
\hline $30^{-}$ & $2.75 \pm 0.08 \quad(7)$ & $2.22 \pm 0.14 \quad(7)$ & 20 & $<0.01$ \\
\hline $44-$ & $2.55 \pm 0.08 \quad(7)$ & $2.03 \pm 0.11(7)$ & 20 & $<0.01$ \\
\hline 60 & $2.59 \pm 0.07$ (8) & $2.06 \pm 0.09(8)$ & 20 & $<0.005$ \\
\hline 150 & $2.61 \pm 0.16(6)$ & $1.99 \pm 0.14$ (6) & 24 & $<0.02$ \\
\hline
\end{tabular}

1.. Housed 1 to a cage.

2. Housed 10 to a cage. 
TABLE .9

EFFECT OF SOCIAL DEPRIVATION OR SOCIAL INTERACTION ON MOUSE BRAIN LEVELS OF GAMMA-AMINOBUTYRIC ACID, GLUTAMIC ACID DECARBOXYLASE, GAMMA-AMINOBUTYRIC ACID TRANSAMINASE AND PROTEIN

\begin{tabular}{|c|c|c|c|c|c|c|}
\hline \multirow{3}{*}{ Measurement } & \multirow{3}{*}{$\begin{array}{c}\text { Social } \\
\text { Environment }\end{array}$} & \multicolumn{5}{|c|}{ Mean + S.E. (N) } \\
\hline & & \multirow{2}{*}{\multicolumn{5}{|c|}{ Days of Social Environment }} \\
\hline & & 1 & & & 30 & \\
\hline \multirow{2}{*}{$\begin{array}{l}\text { GABA } \\
\text { umoles/g } \\
\text { Brain }\end{array}$} & Interaction & $2.44 \pm 0.13 \quad(7)$ & $2.30 \pm 0.08$ & (8) & $2.75 \pm 0.08$ & $(7)$ \\
\hline & Deprivation & $2.43 \pm 0.06^{b}(7)$ & $2.24 \pm 0.15^{b}$ & $(8)$ & $2.22 \pm 0.14^{a}$ & $(7)$ \\
\hline $\begin{array}{l}\text { GAD } \\
\text { umoles } \mathrm{CO}_{2} / \mathrm{s} \\
\text { Brain/hr }\end{array}$ & $\begin{array}{l}\text { Interaction } \\
\text { Deprivation }\end{array}$ & $\begin{array}{l}10.17 \pm 0.45 \mathrm{~b} \\
10.33 \pm 0.68\end{array} \quad\left(\begin{array}{l}6 \\
6\end{array}\right)$ & $\begin{array}{l}10.52 \pm 0.87 \\
10.10 \pm 0.96^{b}\end{array}$ & $\left(\begin{array}{l}6 \\
6\end{array}\right)$ & $\begin{array}{r}10.47 \pm 0.77 \\
7.02 \pm 0.80^{a}\end{array}$ & $\left\{\begin{array}{l}6 \\
6\end{array}\right)$ \\
\hline \multirow[t]{2}{*}{$\begin{array}{l}\text { umoles } \mathrm{CO}_{2} / \mathrm{mg} \\
\text { Protein }\end{array}$} & Interaction & - & - & & $\left.\begin{array}{l}265 \pm 19 c \\
270 \pm 16 d\end{array}\right\}$ & \\
\hline & Deprivation & - & - & & $\begin{array}{l}201 \pm 25^{c} \\
230 \pm 18\end{array}$ & \\
\hline \multirow{2}{*}{$\begin{array}{l}\text { GABA-T } \\
\text { umoles/g } \\
\text { Brain/hr }\end{array}$} & Interaction & - & - & & $227 \pm 8.4$ & \\
\hline & Deprivation & - & - & & $228 \pm 9.6^{\mathrm{b}}$ & \\
\hline \multirow{2}{*}{$\begin{array}{l}\text { Protein } \\
\text { mg Protein/g } \\
\text { Brain }\end{array}$} & Interaction & - & - & & $39.4 \pm 0.03$ & 6) \\
\hline & Deprivation & - & - & & $35.2 \pm 0.04^{a}(1$ & \\
\hline
\end{tabular}


Fapte 9 (Gontinued)

Analysis of Vartance of Data on the Effect of Soctat Peprivation on

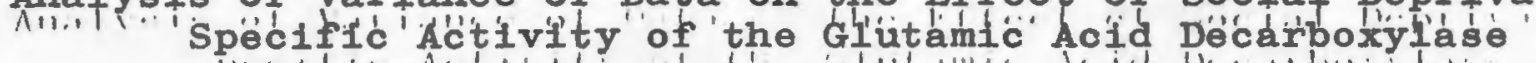

\begin{tabular}{lcccc}
\hline \multicolumn{1}{c}{ Source } & df & MS & F & P \\
\hline Interaction vs. Deprived & 1 & 15980 & 6.55 & $<0.02$ \\
Replicates & 1 & 1596 & 0.65 & $>0.05$ \\
Interaction & 1 & 832 & 0.34 & $>0.05$ \\
Error & $\frac{20}{23}$ & 2438 & - & \\
\hline
\end{tabular}

1. Interaction: housed 10 to a cage; Deprivation: housed 1 to a cage. Interacted vs. Deprived

$a_{p}<0.01 \quad{ }_{p}>0.05$

c. d. Represents values obtained from two separate experiments. 
GABA, but social deprivation for fourteen days resulted in a significant reduction in brain GABA levels. Furthermore, the levels of GABA remained depressed, while there was no further depletion in GABA, when the social deprivation was continued for longer periods of time (Table 8 ).

The effect of social deprivation on the GABA synthesizing enzyme, GAD, and the GABA degrading enzyme, GABA-T, is shown in Table 9. The social deprivation for thirty days resulted in a significant reduction in GAD activity (expressed as umoles of $\mathrm{CO}_{2} / \mathrm{g}$ brain $/ \mathrm{hr}$ ). The specific activity of the enzyme (expressed as nmoles $\mathrm{CO}_{2} / \mathrm{mg}$ protein) was also significantly reduced (Table 9), suggesting that the effect was specific to the enzyme. Thirty days of social deprivation also lowered total protein content of the brain (Table 9). The activity of GABA-T was not affected by social deprivation (Table 9 ).

E. DRUG WITHDRAWAL

It is now well known that abrupt withdrawal following chronic barbiturate (Essig and Lam, 1968) or ethanol (Freund, 1969) administration results in a typical withdrawal syndrome. This syndrome due to barbiturate or alcohol withdrawal is essentially characterized by CNS hyperexcitability, which is observed in the form of convulsions. Barbiturate withdrawal, has previously been reported to lower the CNS sensitivity to barbiturates (Wahlstrom, 1971). In the present study, with the help of biologically. stable barbiturate (barbital), we found that alcohol with- 
drawal-also lowers the neuronal sensitivity to barbiturates (Table 12). These findings suggested that barbiturate or alcohol withdrawal induced CNS hyperexcitability is also accompanied by an alteration in CNS sensitivity to barbiturates. Therefore, we measured brain GABA-1evels following barbiturates and alcohol withdrawal. Since barbiturate or alcohol withdrawal induced CNS hyperexcitability returns to normal over a period of time, we also measured GABA-levels after the hyperexcitability had regressed-to see if the GABA-levels were back to control values.

\section{Bàrbiturate Withdrawa1}

\section{Symptoms}

Approximately $16-24$ hours followine the barbiturate withdrawal, eight out of ten animals showed convulsions upon exposure to an auditory stimulus (loodB for 30 seconds). Control mice did not show any signs of corrulsions upon their exposure to the stimulus.

Upon the exposure of the withdrawn animals to the stimulus-it:was found that, most of the convulsions were associated with loss of upright posture, and they were generalized tonic-clonic seizures of less than a minute duration... Occasionally such convulsions lacked a clonic phase, and infrequently a mouse would remain upright while generalized shaking movements occurred. The last abstinence-convulsions occurred from 42 to 48 hours after the barbiturate was discontinued. 
TABLE 10

EFFECT OF BARBITURATE WITHDRAWAL ON MOUSE BRAIN LEVELS

OF GAMMA-AMINOBUTYRIC ACID

\begin{tabular}{|c|c|c|c|c|}
\hline \multirow{3}{*}{$\begin{array}{l}\text { Hours of } \\
\text { Withdrawal }\end{array}$} & \multicolumn{3}{|c|}{$\begin{array}{l}\text { umoles GABA/E Brain } \\
\text { Mean + S.E. (N) }\end{array}$} & \multirow{3}{*}{$\mathbf{P}$} \\
\hline & \multirow[b]{2}{*}{ Untreated ${ }^{2}$} & \multicolumn{2}{|c|}{ Chrontc Phenobarbital Treated ${ }^{1}$} & \\
\hline & & Convulsed ${ }^{3}$ & Non-Convulsed 4 & \\
\hline 24 & $1.78 \pm 0.09(8)$ & $1.72 \pm 0.11(8)$ & $1.82 \pm 0.08(8)^{5}$ & $>0.05$ \\
\hline 48 & $1.63 \pm 0.13(8)$ & $1.34 \pm 0.17(3)$ & $1.43 \pm 0.14(5)$ & $>0.05$ \\
\hline .120 & $2.57 \pm 0.21 \quad(8)$ & - & $2.54 \pm 0.15 \quad(8)$ & $>0.05$ \\
\hline
\end{tabular}

1. The animals recelved phenobarbital sodium in drinking water, together with $20 \mathrm{mg} / 100 \mathrm{ml}$ saccharin to mask the bitter taste of the barbiturate, in increasting doses over a period of four weeks. The initial dose was $50 \mathrm{mg} / \mathrm{kg} / \mathrm{day}$ and was increased weekly until the animals received $400 \mathrm{mg} / \mathrm{kg} / \mathrm{day}$. During withdrawal mice were given plain drinking water.

2. Untreated animals received saccharln, $20 \mathrm{mg} / 100 \mathrm{ml}$ in drinking water for four weeks. Saccharin solution was replaced by plain drinking water when phenobarbital was withdrawn from the chronically treated animals. The animals were then exposed an auditory stimulus (100 db for 30 seconds) before freezing in liquid nitrogen.

3. The animals showed convulsions within 30 seconds of exposure the stimulus and were then frozen immediately. 


\section{TAPLE to (Continued)}

4. Convulsions were not observed within 60 seconds of exposure to the stimulus átid I'mmediately' after" thät mice weré frozen."

5. The animals were sacrificed 24 hours following the withdrawal without any exposure the stimulus.

6. Different withdrawal hours at which mice were frozen in liquid nitrogen. 
2. Effect on Brain Gamma-aminobutyric Acid

The effect of barbiturate withdrawal on mouse brain GABA-1evels is summarized in Table 10. It demonstrates that 24 or 48 hour withdrawn animals did not differ in brain GABAlevels from untreated animals: Similarly, there was no difference in brain GABA-levels whether these withdrawn animals showed convulsions or not. It can also be seen in Table 9 that 120 hour withdrawn animals did not show any convulsions and that their brain levels of GABA did not differ from untreated animals.

\section{Ethano1 Withdrawa1}

\section{Symptoms}

The maximum intensity of the syndrome was seen in between 5-8 hours following removal of mice from the chamber. Table 11 shows the grading system for assessing the severity of the withdrawal reaction. During the withdrawal, almost all signs of the typical withdrawal syndrome (Goldstein, 1972) were seen; these were: a) spontaneous convulsions, or convulsions elicited either by an auditory stimulus (buzzer used in conditioning apparatus) or by a sharp tap on the cage or by holding the mouse up by the tail, b) lethargy, c) tremor, and d) "tail lift."

The most useful sign to detect the withdrawal induced CNS hyperexcitability was susceptibility of mice to audiogenic seizures; all 5-8 hour withdrawn animals showed either mild clonic- or severe clonic-tonic convulsions upon 
exposure to the auditory stimulus. The smdrome then regressed slowly over the next 24 hours.

\section{Effect on Brain Gamma-Aminobutyric Acid}

Data summarized in Table 13 demonstrate the effect of ethanol withdrawal on brain GABA-levels. The maxim severity of -withdrawal symptoms on (Table 11) as well as an alteration in CNS sensitivity to barbital were (Table 12) observed 8 hours following withdrawal, at which time brain GABA-levels were significantly reduced. Animals which were withdrawn for 5 or 24 hours and those immediately removed from the chamber did not show as severe a withdrawal syndrome and they did not differ from controls with respect: to levels of brain GABA.

Because pyrazole is toxic (Lelbach, 1969), we were concerned about its contribution to the withdrawal induced alteration in barbital narcosis (Table 12) and brain levels of: GABA (Table 13). We, therefore, treated mice with similar:doses of pyrazole, for four days as during the actual experiment but without exposure to ethanol, and measured their response to barbital and their brain levels of GABA (Table-14). It can be seen that pyrazole alone did not produce any significant alteration in narcosis due to barbital or: in brain levels of GABA. 
TABLE 11

ETHANOL WITHDRAWAL SYNDROME

\begin{tabular}{lcccc}
\hline \multirow{2}{*}{ Signs } & \multicolumn{2}{c}{$\begin{array}{c}\text { Degree of Abstinence } \\
\text { Syndrome }\end{array}$} & $\begin{array}{c}\text { Number of } \\
\text { animals that showed } \\
\text { withdrawal reaction }\end{array}$ \\
\cline { 2 - 5 } Lethargy $^{\mathrm{c}}$ & $7^{\mathrm{b}}$ & $3^{\mathrm{b}}$ & $0^{\mathrm{b}}$ & $10 / 12$ \\
Tremor $^{\mathrm{d}}$ & 4 & 2 & 3 & $9 / 12$ \\
Tail lift & 4 & 2 & 0 & $6 / 12$ \\
$\begin{array}{l}\text { Startfe to } \\
\text { noise }\end{array}$ & 3 & 4 & 3 & $10 / 12$ \\
$\begin{array}{l}\text { Audiogenic } \\
\text { seizures }\end{array}$ & 0 & 4 & 8 & $12 / 12$ \\
$\begin{array}{l}\text { Convulsions } \\
\text { handling }\end{array}$ & 0 & 6 & 4 & $10 / 12$ \\
$\begin{array}{l}\text { Spontaneous } \\
\text { convulsions }\end{array}$ & 4 & 0 & 0 & $4 / 12$ \\
\end{tabular}

The mice were removed from the ethanol vapour chamber 24 hours after their last dose of pyrazole. The maximum intensity of the syndrome was seen in between 5 and 8 hours. The syndrome then regressed slowly over the next 24 hours. The animals were observed continuously for 10 hours with scores recorded hourly. Thereafter, observations were made at longer intervals. Control animals did not show any signs of withdrawal reaction. The following controls were run: 1. Six mice were exposed to air (without alcohol) in an identical chamber and were given pyrazole for 4 days, 2. Ten mice were exposed to alcohol vapours for 4 days, but were not given pyrazole.

${ }^{\mathrm{b}}$ Number of animals.

cMild: slow movement, Moderate: slow movement + dragging limbs, Maximum: No movements at all.

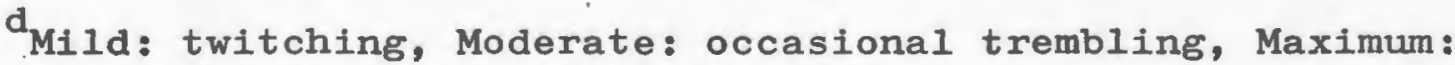
continuous tremors for 5-8 seconds.

"Tail lift" was defined as raising the tail over the back, one of the abnormal postures used in Freund's (1969) grading of the withdrawal signs in mice. Mild: 1 tail lift $/ 60$ minutes, Moderate: 2 tail lift/60 minutes, Maximum: 3-4 tail lift/60 minutes. 
f startle to noise was elicited by a sharp tap on the cage or table. Mild: Twitch lasting for about 2 seconds, Moderate: twitch accompanied by jumping, Maximum: Twitch followed by tonic convulsions.

${ }^{6}$ Exposure of animals to a buzzer (generally used in a conditioning apparatus) produced convulsions within 3 seconds. Moderate: mild clonic convulsions only. Maximum: severe clonic-tonic convulsions ( 4 out of 8 animls died).

\section{$\mathbf{h}$}

Convulsions on handling was defined as holding the mouse up by the tail. The mouse arched his back, tightened his faeial-muscles into an abnormal grimace and jerked or twirled violently. Moderate: tightening of the facial musele, jerking and twirling, Maximum: tightening of the facial-muscle, jerking, twirling and continue to convulse when replaced in the cage.

${ }^{1}$ Mild: tonic, jumping, Moderate: one or two generalized tonic-elonic convulsions per hour, Maximum: three or more generalized tonic-clonic convulsions per hour. 
TABLE 12

DURATION OF BARBITAL NARCOSIS IN MICE WITHDRAWN

FROM ETHANOL

\begin{tabular}{|c|c|c|c|c|}
\hline \multirow[t]{2}{*}{$\begin{array}{l}\text { Hours of } \\
\text { Withdrawal }\end{array}$} & \multirow{2}{*}{$\begin{array}{l}\text { Withdrawal } \\
\text { Syndrome } \\
\text { Intensity }\end{array}$} & \multicolumn{2}{|c|}{$\begin{array}{c}\text { Barbital }{ }^{1} \text { Narcosis, Duration } \\
\text { Min + S.E. (N) }\end{array}$} & \multirow{2}{*}{$\begin{array}{c}\% \\
\text { Change }\end{array}$} \\
\hline & & Control 4 & mental ${ }^{3}$ & \\
\hline 8 & 3 & $140 \pm 8.4(8)$ & $1^{a}(8)$ & 150 \\
\hline 24 & 1 & $132+9.9(7)$ & $5^{b}(6)$ & 28 \\
\hline
\end{tabular}

1. $300 \mathrm{mg} / \mathrm{kg}$ injected intraperitoneal1y.

2. Number of hours after removal of mice from the ethanol vapour-chamber, at which time they were tested with barbital.

3. Prior to withdrawal, mice were given 0.5 umole/kg of pyrazole, i.p., at $0,24,48$ and 72 hours during the total of 96 hours of continuous exposure to an airethanol ( $10 \mathrm{mg}$ ethanol/1iter air) mixture.

4. Controls were exposed concurrently to an air flow (without ethanol) in identical chamber.

5. Numerical grading of the withdrawal syndrome $(1<3)$.

Control vs. Experimental

$a_{p}<0.001$

${ }^{b} \mathbf{p}<0.02$ 
TABLE 13

EFFECT OF ETHANOL WITHDRAWAL ON MOUSE BRAIN LEVELS

OF GAMMA-AMINOBUTYRIC ACID

\begin{tabular}{ccccc}
$\begin{array}{c}\text { Hours } \\
\text { of }\end{array}$ & $\begin{array}{c}\text { Withdrawal } \\
\text { Syndrome } \\
\text { Withdrawal }\end{array}{ }^{1} \begin{array}{c}\text { Intensity } \\
\text { Inteles GABA/g Brain }\end{array}$ & Contro ${ }^{3}$ & Experimenta ${ }^{2}$ & $P$ \\
\hline $0:$ & 0 & $2.48 \pm 0.0(7)$ & $2.56 \pm 0.09(7)>0.05$ \\
$5:$ & 2 & $2.55 \pm 0.11(7)$ & $2.46 \pm 0.12(7)>0.05$ \\
$8:$ & 3 & $2.55 \pm 0.11(7)$ & $1.80 \pm 0.14(7)<0.005$ \\
24 & 1 & $2.38 \pm 0.08(7)$ & $2.36 \pm 0.08(7)>0.05$
\end{tabular}

1. Number:of hours after removal of mice from one ethanol vapour-chamber, at which time they were frozen in liquid nitrogen.

2. Prior to withdrawal, the animals were given 0.5 umoles/ kg of pyrazole, i.p., at $0,24,48$ and 72 hours during the total of 96 hours of continuous exposure to an air-ethanol (10 mg ethanol/liter air) mixture.

3. Controls were exposed concurrently to an air-flow (without ethanol) in identical chamber.

4. Nimerical grading of the withdrawal syndrome $\left(\begin{array}{lll}1 & 2 & 3\end{array}\right)$. 
TABLE 14

EFFECT OF PYRAZOLE ON BARBITAL NARCOSIS AND BRAIN LEVELS OF GAMMA-AMINOBUTYRIC ACID IN MICE

\begin{tabular}{lccccc}
\hline & $\begin{array}{c}\text { Testing } \\
\text { Hour }\end{array}$ & $\begin{array}{c}\text { Ethangl } \\
\text { Hour }\end{array}$ & Control & Experimental & P \\
\hline $\begin{array}{l}\text { Barbital } \\
\text { Narcosis } \\
(\text { min) }\end{array}$ & 32 & 8 & $111 \pm 8.6(8)$ & $104 \pm 9.8(8)>0.05$ \\
& 48 & 24 & $116 \pm 7.2(8)$ & $107 \pm 6.8(8)>0.05$ \\
$\begin{array}{l}\text { umoles GABA/g } \\
\text { brain }\end{array}$ & 32 & 8 & $2.46 \pm 0.09(8)$ & $2.43 \pm 0.10(8)>0.05$ \\
\hline
\end{tabular}

1. Pyrazole $(0.5 \mathrm{umole} / \mathrm{g})$ injected intraperitoneally once a day for four days.

2. Number of hours after the last injection of pyrazole, at which time mice were tested with barbital or frozen in liquid nitrogen for the determination of brain GABA.

3. Number of hours corresponding to ethanol withdrawal.

4. $300 \mathrm{mg} / \mathrm{kg}$ injected intraperitoneally. 


\section{DISCUSSION}

r-: nino butyric acid (GABA) has been shown to play a role as a specific inhibitory transmitter in several areas of the mammalian brain (Krnjevic and Schwariz, 1967; Obata et al., 1967; Otsuka, 1972; Galindo et a.1., 1967). The non-specific depressant effects of GABA on the mammalian CNS have also been demonstrated in various laboratories (Iwama and Jasper, 1957; Bhaegava and Srivastava, 1964). Of all the depressant amino-acids present in the mammalian central nervous system, GABA occurs in the largest amounts; moreover, it occurs uniquely in nervous tissue (Cooper et 21., 1970). Further, unlike the monoamines, the concentration of GABA found in the mammalian central nervous system (CNS) is in the order of umoles/gm ratiner than nmoles/gm. These findings suggest that, an increase in brain levels of GABA due to a specific treatment should reduce the CNS excitability in a way that the sensitivity of the CNS neurons to respond to a depressant drug would be enhanced and vice versa. Therefore, to test our hypothesis, we selected a variety of conditions or treatments already known to either enhance or to reduce the sensitivity of the CNS to drug-induced depression and subjected our animals to the same treatments and measured their brain GABA-levels, in order to investigate a relationship. 
Acute exposure of mice to hypoxia has been reported to enhance the CNS sensitivity to barbiturates (Baumel et al., 1970b). The potentiation of narcosis due to barbital, which is excreted unmetabolized (Ebert et al., 1964), under hypoxia was greater at $22^{\circ} \mathrm{C}$ than at $30^{\circ} \mathrm{C}$ ambient temperature (Baunel et al., 1970b). The hypoxic exposure has also been shown to antagonize convulsions induced by semicarbazide or methionine sulphoximine (Baumel et al., 1969a, b), both drugs decrease brain GABA-levels (Killam and Bain, 1967; Roberts and Franke1, 1951). Data obtained in the research investigation showed that hypobaric exposure elevates brain GABA at both $\left(22\right.$ and $30^{\circ} \mathrm{C}$ ) ambient temperatures (Table 1). Thus, the duration of hypoxia exposure or ambient temperature does not affect or interact with the effect of low ambient oxygen on brain GABA. However, it can be seen in Table 1 that the increase in GABA is comparatively greater, the cause of which is not clear at present, when mice are exposed to hypoxia at the lower ambient temperature.

Breathing of hypoxic air can lead to impairment of brain oxidative metabolism (Gurdjian et al., 1949) with possible reduction in the use of GABA in the shurt pathway of the Kreb's cycle. This causes an increase in brain levels of GABA (Wood et al., 1968), since the formation of the aminoacid by the anarobic enzyme glutamic acid decarboxylase (GAD) is unlikely to be impaired by lack of oxygen (Wood et al., 1968). 
Increase in levels of brain GABA have been related to a reduction in neuronal excitability (Bennett et al., 1963). Therefore, we suggest that hypoxia induced elevation in brain GABA causes reduction in brain excitability, which in turn facilitates drug induced depression.

DMI has been reported to elevate the brain sensitivity to barbiturates at $22^{\circ}$ but not at $30^{\circ} \mathrm{C}$ ambient temperature (Shah and Lal, 1971). This effect of LMI on the brain sensitivity was related to its hypothermic effect (Shal and Lal, 1971). Thus, DMI produces hypothermia and potentiates narcosis due to barbital at $22^{\circ}$ but not at $30^{\circ} \mathrm{C}$ ambient temperature. Our data on DMI's effect on body temperature at both the ambient temperatures (Table 3) is in agreement with the above finding. It was also found that DMI, ambient temperature or their interactions had significant effect on brain GABA-levels. Thus, DMI caused elevation in brain GABA at $22^{\circ} \mathrm{C}$ but not at the higher ambient temperature (Table 3 ). Since $30^{\circ} \mathrm{C}$ ambient temperature also prevented DMI induced hypothermia, it appears that hypothermia due to DMI causes accumalation of brain GABA. In fact, hypothermia has previously been reported to raise brain GABA-levels foja et al., 1968). Furthermore, DMI produces a dose dependent hypothermia at $22^{\circ} \mathrm{C}$ (Shah and Lal, 1971), and our data show that there was a dose-response relationship between the dose of DMI administered and the degree of elevation in brain GABA (Table 4, Figure 7). Considering the aforementioned observations, we suggest that hypothermia induced 
by DMI elevates the brain levels of GABA, resulting in lowered neuronal excitability to be reflected in enhanced barbiturate action.

Sodium nitrite lowers the threshold of brain neurons to drug induced depression at 22 but not at $30^{\circ} \mathrm{C}$ ambient temperature (Baume1 et al., 1971). Like DMI, sodium nitrite produced hypothermia and potentiated narcosis due to barbital at $22^{\circ}$ but not at $30^{\circ} \mathrm{C}$ ambient temperature (Baumel et a1., 1971). However, this effect of sodium nitrite on the brain sensitivity was not related to its hypothermic effect, since direct intracerebral injections of sodium nitrite failed to affect body temperature and narcosis due to a barbiturate (Baumel et al., 1970). Instead, Baumel et al. (1970), related the effects of sodium nitrite on brain excitability and body temperature to its hypoxic effect, because sodium nitrite induces methemoglobinimia (Bodansky, 1951) which in turn impairs the delivery of oxygen to the tissues (Darling and Roughton, 1942), cases hypoxia. In the present study, sodium nitrite elevated brain levels of GABA and produced hypothermia at $22^{\circ} \mathrm{C}$; these effects were abolished at $30^{\circ} \mathrm{C}$ ambient temperature (Table 5). Further support that GABA may be involved facilitating sodium nitrite induced alteration in the threshold of brain neurous, comes from the following findings of Baume1 et al (1971, 1970), 1) sodium nitrite-induced potentiation of barbiturate narcosis was prevented by hyperbaric oxygen (OHP), and 2) sodium nitrite antagonized convulsions induced by semi- 
carbazide, both OHP (Wood et al., 1963) and semicarbazide (Killam and Bain, 1967) reduce brain GABA-levels. These observations suggest that hypoxia induced by sodium nitrite causes accumulation of brain GABA, resulting in lowered neuronel excitability to be reflected in enhanced barbiturate action.

Treatment of mice with pargyline at $22^{\circ} \mathrm{C}$ and at $30^{\circ} \mathrm{C}$ ambient-temperature enhances the narcosis due to barbital (Táble 6), a drug excreted unmetabolized (Ebert et al., 1964), and lowers body temperature (Table 6). Further, pargyline also produces a dose-dependent hypothermia at both the ambient temperatures (Figure 8 ). These observations suggest that pargyline's ability to enhance neuronal sensitivity to barbiturates is due to its hypothermic effect. However, our data on pargyline's effect on brain GABA (Table 6) show that it also raises brain GABA-1evels at both the ambient temperatures. Moreover, there was a dose-response relationship between the amount of pargyline administered and the degree of elevation in GABA (Table 7, Fägure 9). Pargyline has previously been shown to elevate brain levels of GABA in mice (Schatz and Lal, 1971). Therefore, we suggest that hypothermia induced by pargyline causes elevation in brain GABA, resulting in lowered neuronal-excitability to be reflected in enhanced barbiturate aetion.

The ability of pargyline or DMI to elevate brain GABA may at first seem paradoxical since they are used as 
antidepressants, whereas GABA has neuronal inhibitory properties. It may be that GABA is not involved in mood; pargyline's or DMI's effect on GABA is, therefore, not related to their ability to combat depression. Also, our study involved the administration of only a single dose of pargyline or DMI and is, therefore, short term in nature, whereas chronic administration of these drugs is required for their ability to exhibit their antidepressant effect.

Baumel et al. (1970) reported that chronic social deprivation raises arousal levels of mice such that their susceptibility to CNS depressants is reduced. This would predict enhanced effectiveness of CNS stimulants. In fact, chronically isolated mice are hypersensitive to various stimulants (Consolo et al., 1965; Welch and Welch, 1966). The biochemical bases of the higher arousal due to social deprivation is not known. Circumstantial evidence may implicate the involvement of brain serotonin. Higher levels of brain serotonin cause CNS depression (Jouvet, 1.968), while low brain serotonin is associated with insomnia (Delorme et al., 1966). Social deprivation was found to reduce brain serotonin turnover (Garrattini et al. 1967; Giacalone et al., 1968; Valzel1i and Garrattini, 1969; Welch and Welch, 1968). In contrast, barbiturates and chloral hydrate increased the concentration of serotonin (Anderson and Bonnycastle, 1961). Thus, the opposing effects of social deprivation and the CNS depressants on 
brain serotonin could result in the pharmacological antagonism of these drugs. Lal et a1. (1972) reported that depletion of brain serotonin after social manipulation did not alter the sensitivity of either socially deprived or social1y interacted mice to hexobarbital. Since the arousal levels may be related to an altered concentration of an inhibitory transmitter and/or non-specific depressant substance, we measured the GABA levels in the brains of mice after they were subjected to living conditions of social deprivation and social interaction. Data presented in Table 8 show that brain GABA concentrations differed significantly in two groups. The socially interacted group showed higher brain GABA than the socially deprived group. Therefore, we suggest that GABA plays an important role in the control of CNS arousal as altered by social deprivation or interaction. The reduction in GABA activity as in socially deprived mice would be expected to reduce inhibition, or facilitate activation, resulting in an elevated arousal-level.

The cause of lower than normal GABA levels as in socially deprived mice could be either 1) an inhibition of the enzyme synthesizing GABA, glutamic acid decarboxylase (GAD); or 2) a stimulation of the enzyme degrading GABA, GABA-alpha-keto glutaric acid transaminase (GABA-T); or 3) changes in permeability of membranes to GABA which allow the amino acid freer access to the GABA-T enzyme system. Alternatively, a combination of two or more of these possibilities may be involved in lowering GABA following social deprivation. 
We, therefore, measured the activities of the GAD and GABA-T in mouse brain to elucidate the mechanism of decrease in GABA following social deprivation. The activity of $\mathrm{GAD}$, the GABA synthesizing enzyme (Baxter, 1970), was found to be specifically lowered after thirty days of social deprivation, even though there was a small but significant decrease in total protein content of the brain (Table 9). The activity of GABA-T remained unaltered following thirty days of social deprivation. The third possibility that altered membrane permeability could change brain GABA, remains to be studied. Therefore, we suggest that reduced concentrations of GABA as -seen in socially deprived mice are true reflections of biain GAD activity.

The abrupt withdrawal of ethanol following its chronic administration reduces the sensitivity of the CNS to barbital induced depression (Table 12). Barbital was selected for the reason that it is excreted unmetabolized (Ebert et al., 1964). We measured brain GABA in order to establish its relationship with ethanol abstinence-induced alteration in CNS sensitivity to barbiturates. To our knowledge, the decrease in brain GABA as in ethanol withdrawn animals (Table 13) has never been reported before. This decrease-in GABA was evident only in eight hour withdrawn animals; they exhibited most severe abstinence syndrome (Table 13) and a greater degree of reduction in narcosis due to barbital (Table 12), as compared to twentyfour hour withdrawn animals. GABA has previously been implicated in regulation of neuronal excitability (Bennett 
et al., 1963). Since GABA is an inhibitory transmitter, it has also been implicated in the depressant actions of ethanol in the central nervous system (Hakinen and Kulonen, 1961). Considering these properties of GABA, we suggest that lower than normal levels of GABA as in ethanol withdrawn mice causes an increase in neuronal excitability, which is evident in the form of convulsions, so that the potency of a depressant drug is altered.

The use of pyrazole in the ethanol inhalation-experiments requires justification because of its toxicity to liver, when given alone or with ethanol (Lelbach, 1969; Lieber et a1.: 1970). Further, not much is known about pyrazole's action in the brain. The dose of pyrazole used during these studies was less than $1 / 8$ of the LD50 for mice as reported by Goldstein and $\mathrm{Pal}$ (1971). To assess the role of pyrazole in the withdrawal induced-alteration in brain sensitivity to barbiturates (Table 12) and GABA leveis (Table 13), we administered pyrazole alone for four days as during the actual experiment but without ethanol and found that it did not have any effect on brain sensitivity or GABA levels (Table 14). Also, pyrazole alone did not produce any of the ethanol abstinence signs listed in Table 11. Since brain levels of GABA in septal lesioned rats remained unaltered (Table 2 ), it seems that the alteration in brain sensitivity to barbiturates as in the lesioned rats might not be related to changes in brain GABA-levels. Perhaps decrease in the acetylcholine content of the brain 
occurring after septal lesions (Sorensen and Harvey, 1971) might be responsible for the increased sensitivity to barbiturates, since acetylcholine functions as excitatory transmitter in various regions of the brain (Bradley, 1968). Thus, decrease in brain content of acetylcholine could reduce the excitability of brain neurons, which in turn may be responsible for the increased brain sensitivity to barbiturates.

Data presented in Table 10 shows that brain GABAlevels of barbiturate withdrawn mice remained unaltered. This indicates that GABA may not be involved in barbiturate withdrawal induced alteration in brain sensitivity. However, it is possible that barbiturate withdrawal might have altered the rate of turnover of GABA. Or perhaps there were small but significant regional changes in brain GABA that were not reflected in whole brain assays.

Finally, our data obtained by utilizing a variety of conditions such as acute hypoxia, drug treatments, social deprivation or alcohol withdrawal strongly support the hypothesis that there is a correlation between brain sensitivity to barbiturates and brain levels of GABA. Thus, lowering of the threshold of brain neurons to barbiturates caused by hypoxia, desipramine, sodium nitrite or pargyline treatment is accompanied by increase in brain levels of GABA, a neurotransmitter at inhibitiory synapses and/or a non-specific depressant substance. And, increase in the threshold of brain neurons to barbiturates due to chronic 
social deprivation or alcohol withdrawl is accompanied by decrease in brain GABA-levels. The utilization of different classes of drugs with different pharmacological properties, except for desipramine and pargyline both of which possess antidepressant activity but have different mechanisms of action, and environmental conditions helps us to make a generalized conclusion that brain content of GABA plays a very important role in regulating the neuronal sensitivity to drugs. We have thus discovered a specific biochemical mechanism for alteration in neuronal sensitivity to drugs.

Implications of GABA as a specific substance that regulates the neuronal excitability are many. The prior treatment with drugs known to change brain levels of GABA may, therefore, be expected to alter the potency of central nervous system drugs, sometimes in an undesirable manner. The heightened basal level of central nervous system activity (elevated arousal) as in socially deprived mice (Lal et al., 1972), provides suggestion as to the etiology of certain types of schizophrenia. Similar to certain schizophrenic patients (Kornetzky and Mirsky, 1962), socially deprived mice are in a state of overarousal and are less responsive to the central nervous system depressants (Lal et al., 1972). Since the deprivation induced overarousal is related to deficiency of brain GABA, schizophrenic overarousal could also be related to deficiency GABA. However, at best these suggestions are only speculative at this time. 


\section{SUMMARY}

1. Acute exposure to hypoxia elevates brain levels of GABA. Low oxygen due to hypoxia causes alteration in brain metabolism which leads to accumulation of GABA. Since GABA is expected to be involved in the maintenance of appropriate levels of excitability in neurons, an increase in GABA concentrations due to hypoxia would cause reduction in brain excitability. Thus, lowering threshold of brain neurons to drug induced depression.

2. Rats with bilateral stereotaxically placed electrolytic lesions of the septal area of the basal telencephalon demonstrated marked increase in barbital induced-narcosis. The lesions also decreased barbital induction time by one half. These observations suggest that production of septal lesions enhances the depression of brain neurons. GABA is not involved in septal lesion- induced enhancement of neuronal sensitivity to drug induced depression.

3. Injection of desipramine raises brain GABA and lowers body temperature. Hypothermia due to DMI is important in elevation of brain GABA. Higher than normal ambient temperature reduces brain levels of GABA. Higher levels of GABA due to DMI induced-hypothermia reduces the excitability of brain neurors, so that CNS sensitivity to barbiturates is increased. 
4. Injection of sodium nitrite elevates brain GABA and lowers body temperature. Hypothermia due to sodium nitrite is not important in raising brain levels of GABA. We suggest that sodium nitrite induced hypoxia elevates brain GABA which in turn reduces the neuronal excitability.

5. Potentiation of the activity of barbital by pargyline is due to its ability to lower the threshold of brain neurons to drug induced depression. Injection of pargyline lowers body temperature and raises brain GABA. Increase in brain GABA due to pargyline is related to hypothermia. Thus, increased levels of GABA reduces the excitability of brain neurons to such an extert that the potency of CNS depressant drugs is altered.

6. Mice deprived of social interactions show reduced levels of brain GABA. Since GABA is considered to be an inhibitory transmitter, reduction in GABA's activity as in socially deprived mice would be expected to reduce inhibition, or facilitate activation, resulting in an elevated arousal level. This elevation in basal level of CNS activity produces alteration in the potency of central nervous system drugs, Reduced levels of GABA following social deprivation are true reflections of GAD activity. The activity of GABA-T remains unaltered following social deprivation. Chroric deprivation of social stimuli also lowers the amount of total protein in the brain. 
7. Mice develop physical dependence on phenobarbital when their fluid intake is restricted to solutions containing increasing concentrations of the drug. Following withdrawal, convulsions are seen in response to the auditory stimulus. Barbiturate withdrawal-induced alteration in brain sensitivity is not related to changes in brain GABA.

8. Injections of pyrazole stabilizes blood alcohol-1evels. Intoxicating blood levels of ethanol for several days in mice housed in an atmosphere of ethanol vapours produces physical dependence. Upon removal from the alcohol, mice develop spontaneous or the auditory stimulus-induced convulsions. Mice withdrawn from alcohol demonstrated marked decrease in barbital induced narcosis, suggesting that there is a reduction in sensitivity of brain neurons to drug induced depression. Injections of pyrazole alone does not alter brain levels of GABA or brain sensitivity to barbiturates. Brain GABA-levels decreases following alcohol withdrawal. This indicates that reduced levels of GABA increases the excitability of brain neurons so that their sensitivity to depressant drugs is lowered. 


\section{REFERENCES}

Agrawal, H.C., Fox, M.W. and Himwich, W.A.: Neurochemical and behavioral aspects of isolation rearing in the dog. Life Sci. 6 : $71-78,1967$.

Anderson, E.G. and Bonnycastle, D.D.: A study of the central depressant activity of pentobarbital, phenobarbital and diethyl ether in relationship to increase in 5-hydroxytryptamine. J. Pharmacol. Exp. Ther. 130: 138-43, 1961.

Awapara, J., Landau, A.J., Fuerst, R. and Seale, B.: Free T-amino butyric acid in brain. J. Biol. Chem. 187: 35-39, 1950.

Ballantine, E.: Effect of GABA on audiogenic seizures. Colloq. Intern, Centre. Nat1. Rech. Sci. (Paris) 112: 447$51,1963$.

Balazs, R., Dahl, D., and Harwood, J.R.: Subcellular distribution of enzymes of glutamate metabolism in rat brain. J. Neurochem. 13: 897-905, 1966.

Baumel, I.P.: Effect of acute hypoxia or chronic social isolation on brain sensitivity and barbiturate metabolism. Ph.D. Thesis, Dept. Pharmacol. Toxicol. University of Rhode Island, 1970.

Baume1, I.P., DeFeo, J.J. and Lal, H.: Alteration in brain sensitivity and barbiturate metabolism unrelated to aggression in socially deprived mice. Psychopharmacologia 18: $320-24,1970 a$.

Baume1, I.P., DeFeo, J.J. and Lal, H.: Effect of acute hypoxia on brain sensitivity and metabolism of barbiturates in mice. Psychopharmacologia 17: 193-97, 1970b.

Baume1, I.P., Pitterman, A.B., DeFeo, J.J. and Lal, H.: Nitrite induced enhancement of neuronal sensitivity to barbiturates and deceleration of barbituate metabolism: Effect of high ambient temperature or oxygen under high pressure (OHP). Pharmacologist 13: 289, 1971.

Baumel, I., Robinson, S.M. and Blatt, W.F.: Multi-chamber system for toxicity studies in mice at simlated high altitude. J. Pharm. Sci. 56: 918-19, 1967. 
Baume1, I., Schatz, R., DeFeo, J,J. and Lal, H.: Protection against semicarbizide-induced convulsions in mice at hypobaric pressure. J. Fharm. Pharmacol. 21: 119-20, 1969a.

Baumel, I., Schatz, R., DeFeo, J.J. and Lal, H.: Hypoxia and methionine sulphoximine seizures in mice. J. Pharm. Pharmacol. 21: $703-4,1969 \mathrm{~b}$

Baumel, I., Schatz, R., DeFeo, J.J. and Lal, H.: Protection against m-fluorotyrosine convulsions and lethality in mice exposed to hypobaric hypoxia. J. Pharm. Pharmacol. 21: 475$-6,1969 c$.

Baster, $C . F .:$ The nature of gamma-amino butjric acid. In: ancibouk of Neurochemistry; vol. III, pp. 289-353, ed. Abel iajtha, Plenum Press, N.Y., 1970.

Baxter, C.F. and Roberts, E.: The gamma-amino butyric acidalpha-ketoglutaric acid transaminase of beef brain. J. Bio1. Chem. 233: 1135-39, 1958.

Bennett, M., Aljure, E., Narajima, Y. and Pappas, A.D.: Electronic junctions between teleost spinal neurons: Electrophysiology U1trastructure. Science 141: 262-4, 1963.

Bergeret, B., and Chatagne, F.: Sur la presence d'acide cystenesulfinique dans le cerveau du rat normal. Biochem. Biophys. Acta, 14: 297, 1954.

Bermardini, A.T.: Influence of reduced pressure on administered drugs. Pharmacologist 11: 223, 1969.

Bhargava, K.P. and Srivastava, R.K.: Non-specific depressant action of gamma-amino butyric acid on somatic reflexes. Brit. J. pharamco1. 23: 391-98, 1964.

Bindman, L.J., Lippold, O.C.J. and Redfearn, J.W.T.: The non-selective blocking action of gamma-amino butyric acid on the sersory cerebral cortex of the rat. J. Physiol. (Lond.) 162: 105-120, 1962.

Bodansky, O.: Methemoglobinemia and methemoslobin producing compounds. Pharmacol. Rev. 2: 144-96, 1951.

Bradley, P.B.: Symaptic transmission in the central nervous system and its relevance for drug action. In: Internetional Review of Neurobiologr, Vol. II, eä. by C.C, Pfeiffer and J.R. Smythies, pD. 2-53, Academic Press, New York, 1968.

Bustos, G.O., Kalant, H., Khanna, J.M. amu Loth, J.: Pyra?ole and induction of fatty liver by a single dose of athanol. Science 168: 1598-99, 1970.

Carlton, P.L.: Potentiation of the behavioral effects of amphetamine by imipranine. Psychopharmacologia 2: 364-76, 1961. 
Chance, M.R.A.: The contribution of environment to uniformity. Coll. Pap. Lab. Anim. Bur. 6: 59-63, 1957.

Chance, M.R.A. and Mackintosh, J.H.: The effects of caging. Col1. Pap. Lab. Anim. Bur. 11: 59-62, 1962.

Consolo, S., Garrattini, S. and Valzelli, L.: Amphetamine toxicity in aggressive mice. J. Pharm. Pharmaco1. 17: 53-54, 1965.

Crossland, J. and Leonard, B.E.: Barbiturate withdrawal convulsions in the rat. Biochem. Pharmacol. Suppl. 12: 103, 1963.

Curtis, D.R. and Watkins, J.C.: In Inhibition in the Nervous System and Gamma-Aminobutyric Acid. E. Roberts, C.F.

Baxter, A. Van Harreveld, C.A.G. Wiserman, W.R. Adey and K.F. Killam (eds), pp. 424-444, Pergamon Press, New York, 1960.

Darling, R.C, and Roughton, F.J.: The effect of methemoglobin in the equilibrium between oxygen and hemoglobin. Amer. $\mathrm{J}$. Playsiol. 137: 56-58, 1942.

Davidoff, R.A.: Gamma-amino butyric acid antagonism and presynaptic inhibition in the frog spinal cord. Science 175: $331-32,1972$.

Delorme, R., Fremont, J.L. and Jouet, M.: Supression du sommeil par la p-chloromethamphetamine et la p-chlorophenylalanine. C.R. Soc. Biol. (Paris) 160: 2347-51, 1966.

Dixon, W.J. and Massey, F.J.: Introduction to statistical analysis. McGraw-Hil1, New York, 1969, 3rd edition.

Ebert, A.G., Yim, G.K. and Miya, T.: Distribution and metabolism of barbital $\mathrm{C}^{14}$ in tolerant and non-tolerant rats. Biochem. Pharmacol. 13: 1267-74, 1964 .

Ehinger, B. and Falck, B.: Autoradiography of some suspected neurotransmitters substances: GABA, glycine, glutamic acid, histamine, dopamine and 1-DNPA. Brain. Research 33: $157-72,1971$.

Ellis, F.W., Pick, J.R.: Ethanol induced withdrawal reactions in rhesus monkeys. Pharmacologist 11: 256, 1969.

Essig, C.F.: Barbiturate withdrawal in white rats. Int. J. Neuropharmacol. 2: 103-7, 1966.

Essig, C.F.: Clinical and experimental aspects of barbiturate withdrawal convulsions. Epilepsia 8: 21-30, 1967. 
Finley, T.N., Swensom, E.W., and Consroe, J.H., Jr.: The cause of arterial hypoxemia in patients with "alveolarcapillary block syndrome." J. Clin. Invest. 41: 618-25, 1962.

Folk, E. G.: Low pressure from terrestrial altitude. In: Introduction to Environmental Physiology. pp. 213-38, Lea and Febiger, Philadelphia, 1966.

Freund, G.: Alcohol withdrawal syndrome in mice. Arch. Neuro1. 21: 315-20, 1969.

Freund, G., and Walker, D.W.: Sound-induced seizures during ethanol withdrawal in mice. Psychopharmacologia 22: $45-49,1971$.

Galindo, A., Krnjevic, K. and Schwartz, S.: Microiontophoric siudies on neurons in the cuneate nucleus. J. Physiol. (Lond.) 192: 359-77, 1967.

Garrattini, S., Giacolone, E., and Valzell1, L.: Isolation aggressiveness and 5-hydroxytryptamine turnover. J. Pharm. Pharmacol. 19: $338-39,1967$.

Garrattini, S. and Jori, A.: Interactions between imipramine like drugs and reserpine on temperature. In: First International Symposium on Antidepressant Drugs, Congress Series No. 122, ed. by S. Garrattini and M.N.G. Dukes, pp. 179-93, Excerpta Medica Foundation, Amsterdam, 1967.

Giacalone, E., Tansella, M., and Valzelli, L, and Garrattini, S.: Brain serotonin metabolism in isolated aggressive mice. Biochem. Pharmaco1. 17: 1315-27, 1968.

Goldberg, L, and Ryberg, V.: Inhitition of ethanol metabolism in vivo by administration of pyrazole. Biochem. Pharmacol. 18: $1749-62,1969$.

Goldstein, D.B., and Pal, N.: Alcohol dependence produced in mice by inhalation of ethanol: grading the withdrawal reaction. Science 172: 288-90, 1971.

Gordon, E.R.: The effect of ethanol on the concentration of $\gamma$-aminobutyric acid in the rat brain. Can. J. Physiol. Pharmaco1. 45: 915-18, 1967.

Graham, L.T. and Aprison, M.H.: Fluorometric determination of aspartate, glutamate and -aminobutyrate in nerve tissue, using enzymic methods. Anal. Biochem. 15: 487-97, 1966 .

Guerrero-Figueroa, R., DeBalbian Verster, F., Barros, A. and Heath, R.G.: Cholinergic mechanism in subcortical mirror focus and effects of topical application of GABA and acetylcholine. Epilepsia 2: 140-55, 1964. 
Gurdjian, E.S., Webster, J.E. and Stone, W.E.: Cerebral constituents in relation to blood gases. Amer. J. Physiol. 156: $149-157,1949$.

Hagen, D.Q.: GABA levels in rat brain after prolonged ethanol intake. Quart. J. Stud. Alc. 28: 613-17, 1967.

Hakkinen, H.M. and Kulonen, E.: The effect of ethanol on the aminoacids of the rat brain with reference to the administration of glutamine. Biochem. J. 78: 588-93, 1961.

Hakkinen, H.M. and Kulonen, E.: Comparison of various methods for the determination of GABA and other amino acids in rat brain with reference to ethanol intoxication. J. Neurochem. 10: $489-94,1963$.

Harvey, J.A.: Comparison between the effects of hypothalamic lesions on brain amine levels and drug action. J. Pharmacol. Exp. Ther. 147: 244-51, 1965.

Harvey, J.A., Heller, A. and Moore, R.Y.: The effect of unilateral and bilateral medial forebrain lesions on brain serotonin. J. Pharmacol. Exp. Ther, 140: 103-10, 1963.

Harvey, J.A., Heller, A., Moore, R.Y., Howard, H.F., and Roth, L.J.: Effect of central nervous system lesons on barbiturate sleeping time in the rat. J. Pharmacol. Exp. Ther. 144: 24-36, 1964 .

Hatch, A., Balaz, T., Wiberg, G.S. and Grice, H.C.: Long term isolation stress in rats. Science 142: 507-12, 1963.

Heller, A., Harvey, J.A., Hunt, H.F. and Roth, L.J.: Effect of lesions in the septal forebrain of the rat on sleeping time under barbiturate. Science 131: 662-63, 1960.

Heller, A., Harvey, J.A. and Moore, R.Y.: A demonstration of fall in brain serotonin following central nervous system lesion in the rat. Biochem. Pharmacol. 11: 859-66, 1962.

Heller, H., Hardan, G. and Zaidi, S.M.: Seasonal variation in the response of rats to the antidiuretic hormone. Brit. J. Pharmacol. 12: 100-5, 1957.

Isbe11, H., Altschul, S., Kornetsky, C.H., Eisenman, Anna J., Flanary, H.G. and Fraser, H.F.: Chronic barbiturate intoxication: An experimental study. Arch. Neurol. Psychiat. (Chicago) 64: 1-28, 1950.

Iwama, K. and Jasper, H.H.: The action of gamma-amino butyric acid upon cortical electrical activity in the cat. J. Physiol. (Lond.) 138: $365-80,195 \%$. 
Jaffe, J.H. and Sharpless, S.K.: The rapid development of physical dependence on a barbiturate. J. Pharmaco1. Exp. Ther. 150: 140-45, 1965.

Jori, A. and Garrattini, S.: Interaction between imipramine-like agents and catecholamine-induced hyperthermia. J. Pharm. Pharmacol. 17: 480-88, 1965.

Jouvet, M.: Neuropharmacological basis for the role of 5-HT in sleep mechanisms. Advanc. Pharmacol. 68: 267-69, 1966.

Killam, K.F. and Bain, J.A.: Convulsant hydrazides I: In vitro and in vovo inhibition of $B_{6}$ enzymes by convulsant hydrazides. J. Pharmacol. Exp. Ther. 119: 255-62, 1957.

Kimbrel1, G.M.: A preliminary analysis of the agonistic behavior patterns shown by three strains of mice, mus musculus, in the foot shock situation. Ph.D. Dissertation, Dept. Psychol., University of Tennessee, 1967.

King, J.J., Chiun, G., Pum Lee, Y. and Visscher, M.B.: Single versus multiple occupancy and convulsion frequency in $\mathrm{C}_{3} \mathrm{H}$ mice. Proc. Soc. Exp. Biol. (N.Y.) 88: 661-63, 1955.

Kobrin, S. and Seifter, J.: -amino acids and various biogenic amines as antagonists to pentylenetetrazole. J. Pharmaco1. Exp. Ther. 154: 646-51, 1966.

Kopeloff, L.M. and Chusid, J.G.: Pyridoxine and GABA as antagonists to drug induced convulsions in monkeys. J. App1. Physio1. 20: 1337-40, 1965.

Kornetsky, C. and Mirsky, A.F.: On certain psychopharmacological and physiological differences between schizophrenic and normal patients. Psychopharmacologia 8: 309-18, 1966.

Kravitz, E.A., Molinoff, P.B. and Hall, Z.W.: A comparison of the enzymes and substrates of gamma-amino butyric acid metabolism in lobster excitatory and inhibitory axons. Proc. Nat1. Acad. Sci. U. S. 54: 778-82, 1965.

Krnjevic, K. and Schwartz, S.: Is gamma-aminobutyric acid an inhibitory transmitter? Nature 211: 1372-74, 1966.

Lal, H., DeFeo, J.J., Pitterman, A., Patel, G. and Baume1, I.: Effects of prolonged social deprivation or enrichnent ori neuronal sensitivity for CNS depressants and stimulants. In: Drug Addiction: Experimental Pharmacology, Vol. I, ed. by J. M. Singh, L. H. Miller and H. Lal, pp. 255-66, Futura Publishing Co., Now York, 1972. 
Lamar, C. Jr. and Sellinger, 0.Z.: The inhibition in vivo of cerebral glutamine synthetase and glutamine transferase by the convulsant methionine sulphoximine. Biochem. Pharmacol. 14: 489-506, 1965.

Lelbach, W.K.: Liver cell necrosis in rats after prolonged ethanol ingestion under the influence of an alcohol dehydrogenase inhibitor. Experientia (Basel) 25: 816-18, 1969.

Lester, D., Keokosky, W.Z. and Felzenberg, F.: Effect of pyrazole and other compounds on alcohol metabolism. Quart. J. Stud. Alc. $29: 449-54,1968$.

Lleber, C.S., Rubin, E., DeCarli, L.M., Mirsa, P. and Gang, H.: Effects of pyrazole on hepatic function and structure. Lab. Invest. 22: $615-21,1970$.

Lowry, O.H., Rosenbrough, N.J., Farr, A.L. and Randa11, R.J.: Protein measurement with the folin phenol reagent. J. Biol. Chem. 193: 265-75, 1951 .

Lundquist, F.: The determination of ethyl alcohol in blood and tissues. Methods Biochem. Anal. 1: 217-51, 1959.

McQuarrie, D.G. and Fingl, E.: Effects of single doses and chronic administration of ethanol on experimental seizures In mice. J. Pharmacol. Exp. Ther. 124: 264-71, 1958.

Morgan, J.C. and Diluzio, N.R.: Inhibition of the acute ethanol induced fatty liver by pyrazole. Proc. Soc. Exp. Bio1. Med. 134: 462-66, 1970 .

Norton, P.R.E.: The effects of drugs on barbiturate withdrawal convulsions in the rat. J. Pharm. Pharmacol. 22: $763-66,1970$.

Obata, K., Ito, M., Ochi, R. and Sato, N.: Pharmacologic properties of the post synaptic inhibition by purkinje cell axons and the action of gamma-amino butyric acid on Deiters neurons, Expt1. Brain. Res. 4: 43-57, 1967.

Oja, S.S., Oja, H. and Sarajas, H.S.S.: Cerebral free amino acids in the rats undergoing varying periods of anaesthesia and hypothermia. Ann. Acad. Sci. Fern. Ser. A II Chem. 142: 3-14, 1968 .

Oswald, N. and Fry, J.: Diseases of the respiratory system, F.A. Davis Co., Philadelphia, 1962.

otisuka, M.: GABA and scme other trarsmitter candidates in the nervous systein. Fifth Int. Cong. Pharmacol. Abstracts of Invited Presentations; pp. 16-17, 1972. 
Otsuka, M., Iverson, L.L., Hal1, Z.W. and Kravitz, E.A.: Release of gamma-amino butyric acid from inhibitory nerves of lobster. Proc. Nat1. Acad. Sci. U. S.: 56: 1110-15, 1966.

Pasquini, J.M., Salomane, J.R. and Gomez, C.J.: Amino acid changes in the mouse brain during audiogenic and recovery. Exp. Neuro1. 21: 245-56, 1968.

Pisano, J.J. and Udenfriend, S.: Formation of guanidebutyric acid and guanido-acetic acid in brain. Fed. Proc. 17: $403,1958$.

Purpura, D.P., Giardo, M. and Grundfast, H.: Selective blockade of excitatory synapses in the cat brain by gamma-amino butyric acid. Science 125: 1200-2, 1957.

Rech, R.H. and Domino, E.F.: Effects of gamma-amino butyric acid on chemically and electrically evoked activity in the isolated cerebral cortex of the dog. J. Pharmacol. Exp. Ther. 130: 59-67, 1960 .

Roberts, E.: Formation and liberation of gamma-amino butyric acid in brain. In: Progress in Neurobiology. I. Neurochemistry. ed. by S. R. Korey and J. I. Nurnberger. pp. 11-25, Hoeber-Harper, New York, 1956.

Roberts, E. and Frankel, S.: Gamma-amino butyric acid in brain. Its formation from glutamic acid. J. Biol. Chem. 187: $55-63,1950$.

Roberts, E. and Frankel, S.: Further studies of glutamic acid decarboxyalse in brain. J. Biol. Chem. 190: 505-12, 1951 .

Roberts, E. and Kuriyama, K.: Biochemical physiological correlations in studies of the gamma-amino butyric acid system. Japan. Life Sci. Tokyo (Seitai-no-Kagaku) 15: 2-27, 1967, Brain Res. 18: 1-35.

Roberts, E. and Simonsen, D.G.: Some properties of 1-glum tamic acid decarboxylase in mouse brain. Biochem. Pharmacol. 12: $113-34,1953$.

Robinson, S.M., Blatt, W.F., Schatz, R, and Joy, R.: The effects of simulated altitude and aggregation cn hexobarbital sleeping time in mice. Fed. Proc. 27: 282, 1968.

Roth, B.F. and Harvey, J.A.: Altered response of cerebral respiration to thiopental and potesstum ions in vitro after septal lesions. J. Pharmacol. Exp. Ther. 161: 155-62, 1968.

Rubin, E., Gang, H. and Lieber, C.S.: Interaction of ethanol and pyrazole with hepatic microsomes. Biochem. Biophys.

Res. Commun. 42: 1-8, 1971. 
Salganicoff, L. and DeRobertis, E.: Subcellular distribution of the enzyme of the glutamic acid, glutamine and gamma-amino acid cycles in rat brain. $J$. Neurochem. 12: 287-309, 1965.

Salvador, R.A. and Albers, R.W.: The distribution of glutamic - $\gamma$-aminobutyric transaminase in the nervous system of the rhesus monkey. J. Biol. Chem. 234: 922-25, 1959.

Schatz, R.A. and Lal, H.: Elevation of brain GABA by pargyline: a possible mechanism for protection against oxygen toxicity. J. Neurochem. 18: 2553-55, 1971.

Schlesinger, K., Boggan, W. and Freedman, D.X.: Genetics of audiogenic seizures: II Effects of pharmacological manipulation of brain serotonin, norepinephrine and gammaamino butyric acid. Life Sci. I: 437-47, 1968.

Seguin, J.J. and Stavraky, G.W.: The effects of barbiturates on partially isolated region of the central nervous system. Canad. J. Biochem. Physiol. 25: 667-80, 1957.

Shah, H. and Lal, H.: The potentiation of barbiturates by desipramine in the mouse: mechanism of action. J. Pharmacol. Exp. Ther. 179: 404-9, 1971.

Sigg, E.B., Day, C.A. and Colombo, C.: Endocrine factors in isolation-induced aggressiveness in rodents. Endocrinology 78: 679-84, 1966 .

Simpson, J.R., Grabarits, F. and Harvey, J.A.: Differential effects of central nervous system lesions on brain amines and reserpine action in the rat. Pharmacologist 2: 213, 1967.

Sjoqvist, F, and Gillette, J.: Prolongation and potentiation of oxotremorine effects by desmethylimipramine, an "anti-tremorine" drug. Life Sci. 4: 1031-36, 1965.

Sorenson, J.P. and Harvey, J.A.: Decreased brain acetylcholine after septal lesions in rats: correlation with thirst. Physiology and Behavior 6: 723-725, 1971.

Stevenson, I.H. and Turnbul1, M.J.: The sensitivity of the brain to barbiturate during chronic administration and withdrawal of barbitone sodium in the rat. Br. J. Pharmaco1. 29: 325-333, 1970. 
Takeuchi, A. and Takeuchi, N.: Localized action of gammaamino butyric acid on the crayfish muscle. J. Physiol. (Lond.) 177: 225-38, 1965.

Tallan, H.H., Moore, S. and Stein, W.H.: Studies on the free aminoacids and related compounds in the tissues of cat. J. Biol. Chem. 211: 927-39, 1954.

Theorell, H., Yonetani, T. and Sjoberg, B.: On the effects of some heterocyclic compounds on enzymic activity of liver alcohol dehydrogenase. Acta Chem. Scand. 23: 255-60, 1969.

Udenfriend, S.: Identification of gamma-amino butyric acid in brain by isotope derivitive method. J. Biol. Chem. 187: $65-69,1950$.

Valzelli, L. and Garrattini, S.: Behavioral changes and serotonin turnover in animals. Advanc. Pharmacol. 6B: 249-60, 1969.

Van Liere, E.J. and Stickney, J.C.: Hypoxia, University of Chicago Press, Chicago, 1963.

Wahlstrom, G.: Hexobarbital (enhexymalian NFN) sleeping times and EEG threshold doses as measurements of tolerance to barbiturates in the rat. Acta Pharmaco1. (Kbh.) 26: $64-80,1968$.

Wahlstrom, G.: Chariges in hexobarbital anaesthesia threshold in rats indiced by repeated long term treatment with

barbital or ethanol. Psychopharmacologia 19: 366-80, 1971.

Wallach, D.P.: Studies on the GABA pathway-I. Biochem. Pharmacol. 5: 323-31, 1961.

Welch, A.S. and Welch, B.L.: Effects of stress and p-chlorophenylalanine upon brain serotonin, 5-hydroxyindoleacetic acid and catecholamines in grouped and isolated mice. Biochem. Pharnacol. 17: 699-708, 1968.

Wenzel, D.G. and Lal, H.: The relative reliability of the escape reaction and righting reflex sleeping times in the mouse. J. Amer. Phar. Assoc. (Sci. ed.) 48: 90-91, 1959.

Wiechert, P. and Herbst, A.: Provocation of cerebral seizures by derangement of the natural balance between glutamic acid and -amino butyric acid. J. Neurochem. 13: $59-64,1956$.

Wolfe, L.S. and Elliot, K.A.C.: Chemical studies in relation to convulsive disorders. In: Neurochemistry, ed. by K.A.C. Elliott, I.H. Page and J.H. Quastel, pp. 694-727. Charles C. Thomas, Springfield, Illinois, 1962. 
Wood, J.D. and Watson, W.J.: Gamma-amino butyric acid levels in the brain of rats exposed to oxygen at high pressure. Can. J. Biochem. Physio1. 41: 1907-13, 1963.

Wood, J.D., Watson, W.J. and Drucker, A.J.: Oxygen poisoning in various mammalian species and the possible role of GABA metabolism. J. Neurochem. 14: 1067-74, 1967.

Wood, J.D., Watson, W.J. and Drucker, A.J.: The effects of hypoxia on brain GABA levels. J. Neurochem. 15: 603-8, 1968.

Yen, C.Y., Stanger, R.L. and Millman, N.: Ataractic suppression of isolation-induced aggression behavior. Arch. Int. Pharmacodyn. 123: 179-85, 1959.

Zuromski, E.S., Donovick, P.J. and Burright, R.G.: Barpressing for illumination change in albino rats with septal lesions. J. Comp. Physiol. Psychol. 78: 83-90, 1972. 